\title{
Effect of Ecotype and Latitude on Growth, Frost Hardiness, and Oxidative Stress of South to North Transplanted Scots Pine Seedlings
}

\author{
Erja Taulavuori, ${ }^{1}$ Kari Taulavuori, ${ }^{1}$ Ahti Niinimaa, ${ }^{2}$ and Kari Laine ${ }^{3}$ \\ ${ }^{1}$ Department of Biology, University of Oulu, P.O. Box 3000, 90014 Oulu, Finland \\ ${ }^{2}$ Department of Dentistry, University of Oulu, P.O. Box 5281, 90014 Oulu, Finland \\ ${ }^{3}$ Thule Institute, University of Oulu, P.O. Box 7300, 90014 Oulu, Finland
}

Correspondence should be addressed to Kari Taulavuori, kari.taulavuori@oulu.fi

Received 6 September 2010; Accepted 1 December 2010

Academic Editor: Michael Tausz

Copyright ( $) 2010$ Erja Taulavuori et al. This is an open access article distributed under the Creative Commons Attribution License, which permits unrestricted use, distribution, and reproduction in any medium, provided the original work is properly cited.

\begin{abstract}
Ecotypes of Pinus sylvestris seedlings from Kuhmo $\left(64^{\circ} \mathrm{N}\right)$ and Ranua $\left(66^{\circ} \mathrm{N}\right)$ were transplanted to 0 (control), 1,2 , and $3^{\circ} \mathrm{N}$ higher latitude in Northern Finland in 1997. Sampling was carried out twice per year (spring/autumn) during 1998-2000. Shoot elongation, total nitrogen concentration, frost hardiness and oxidative stress state (lipid peroxidation, glutathione reductase activity, and protein oxidation) in the needles were analyzed. Comparison between the seasonal sampling times indicated that total nitrogen, lipid peroxidation, glutathione reductase activity, and protein oxidation were lower in autumn, during which the frost hardiness was higher. The above suggests that the stress conditions were higher in spring. Comparison between the origins of the seedlings demonstrated that shoot elongation of the northern origin were minor, while their total nitrogen concentrations and frost hardiness were more pronounced. Effect of latitude on elongation of Scots pine is most probably a result of a combination of temperature and light quality. No delay in frost hardening due to higher latitude was observed during the autumnal equinox. No marked stress caused by transplantation to the north was either observed. It is concluded that southern ecotypes of Scots pine have the potential to adapt to migration driven by a warming climate.
\end{abstract}

\section{Introduction}

Many physiological changes in seasonality of trees (growth, frost hardening, etc.) are synchronized by annual changes in day length, and the day length is determined by latitude at a given time. Plant ecotypes at a particular site are genetically adapted to the local environment. However, phenotypic plasticity also enables plants to acclimate to changing environmental conditions.

Plant individuals are rooted to their growing sites, but they can migrate over long distances as seeds (or spores). The seeds bear new seedlings and eventually mature individuals establish themselves on sites where environmental conditions are favorable for growth. Low temperature is the main barrier for geographical distribution of plants towards northern areas. Therefore, migration of southern plant species and ecotypes towards the north could be expected under a warming climate [1].

There is increasing consensus that the climate is currently warming at a high rate. Current atmospheric $\mathrm{CO}_{2}$ concentration is predicted to double by the end of this century, which results in climatic warming of $4-7^{\circ} \mathrm{C}$ in the northern boreal zone $[1,2]$. Consequently, distribution of boreal forests obviously shifts to the current Tundra areas [1]. It is thus obvious that northern plants will experience a dramatically changed annual photoperiod in the near future, since the amplitude in the change of annual day length increases towards the north. In addition to day length and quantity of light, climate also includes changes in light quality [3].

There are multiple physiological variables that could be used to provide insight concerning plant survival and wellness in a given environment. Probably the simplest 


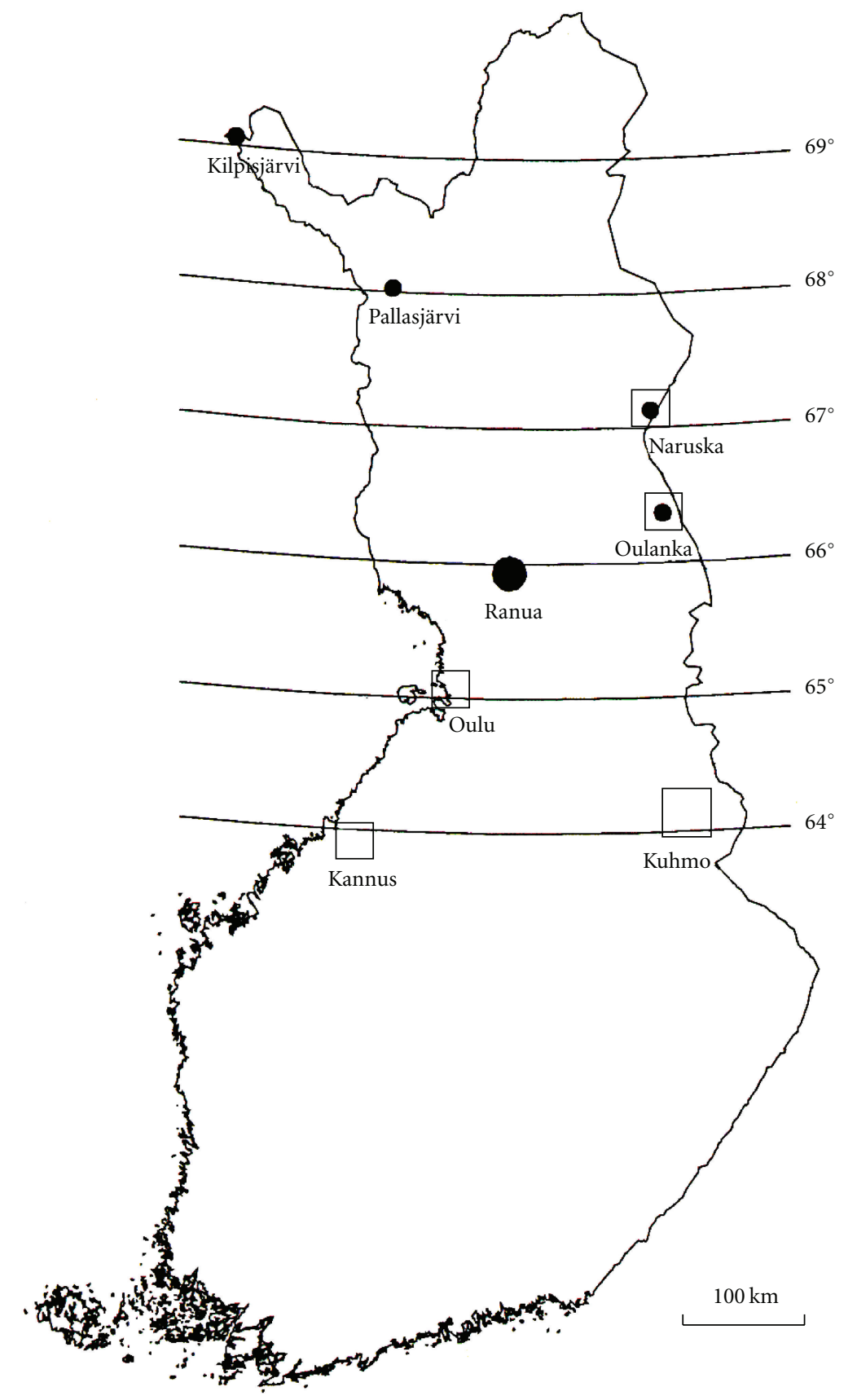

FIgUre 1: Map of transplantations for the ecotypes Kuhmo $(\square)$ and Ranua $(\bullet)$.

indicator, by means of analysis procedure, is elongation, that is, vertical growth. In Scots pine this is controlled by both previous- and current-year temperature (e.g., [4]). Therefore, less elongation could be expected under conditions of lowering temperatures. Chemical elements may also indicate plant acclimation to a variable environment. Total nitrogen concentration, for example, may accumulate in cold climates [5]. Frost hardiness, that is, ability to withstand subzero temperatures, is important for survival in cold environments. The frost hardening process is mainly controlled by two factors: lowering temperatures and extending night length [6]. Thus, plants transplanted to the north obviously exhibit better frost hardiness due to the colder environment. However, as the days are longer in the north during late summer and early autumn, the development of frost hardening may thereby be delayed. Biochemical compounds may be used to provide information about stress responses to the environment. Oxidative stress and consequent lipid peroxidation increases in the cold and towards winter [7-11]. Glutathione reductase (GR) is an enzyme that catalyzes the reduction of glutathione disulfide (GSSG) to the reduced form of glutathione (GSH). In principle, the higher the oxidative stress and consequent GSSG concentration, the higher the GR activity required 


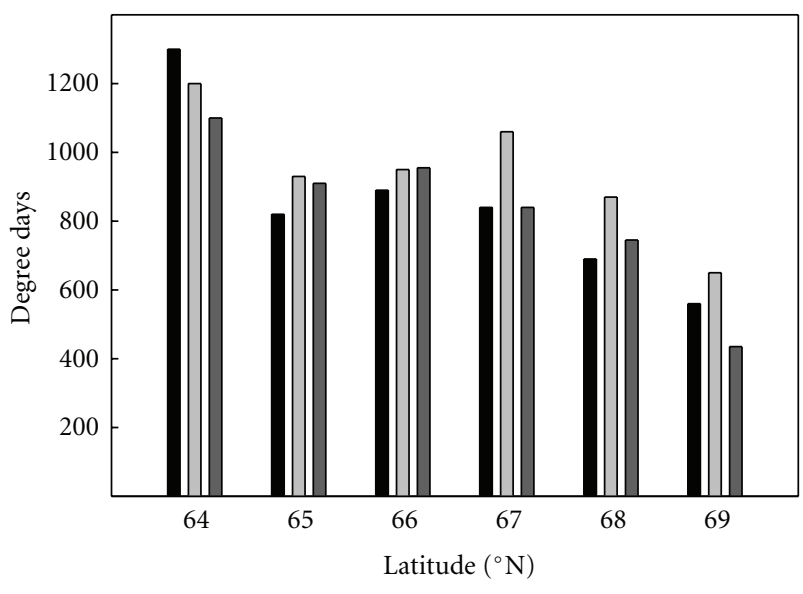

(a)

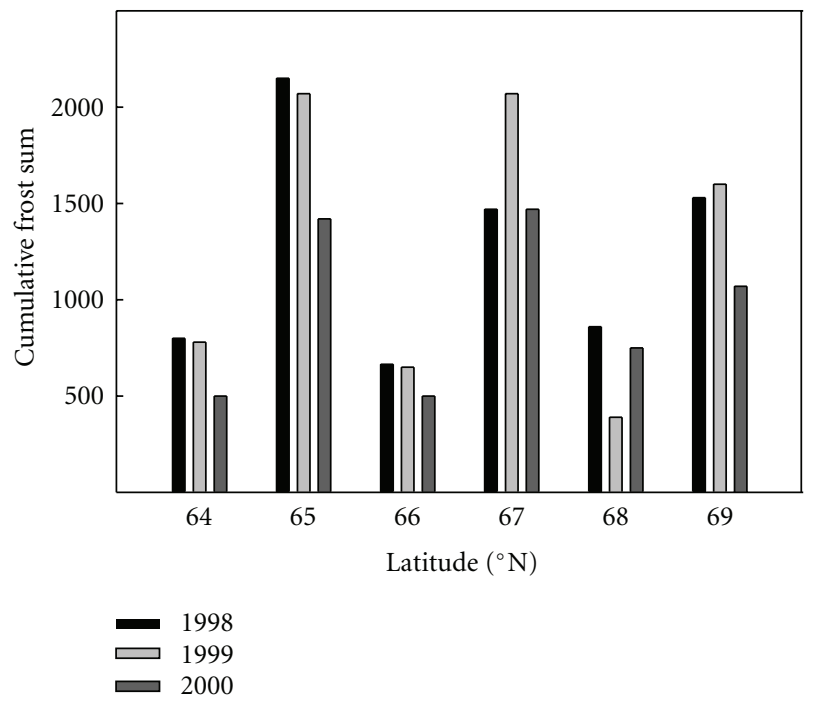

(b)

Figure 2: Degree days (a) and cumulative frost sum (b) at the transplantation sites at the seedlings heights during 1998-2000.

to maintain cells in a reduced state. In accordance, GR activity in Scots pine needles increases during cold hardening $[12,13]$. Severe stress may also result in protein oxidation and subsequent degradation $[14,15]$. While the amount of soluble proteins indicates stress responses, they also change seasonally from low summer to high winter concentrations [16].

The aim of this work was to study plant growth, seasonal hardening status and stress response of Scots pine in an experiment of transplantation towards north. Two ecotypes from different latitudes were compared to test whether or not geographic origin affects stress tolerance in a new environment. We hypothesize that: (1) growth of the Scots pine seedlings is decreased along an increasing latitude due to a decrease in annual temperature sum, but changed light conditions may also have an effect to some extent, (2) frost hardiness of the seedlings in autumn is delayed along increasing latitude, and (3) stress response is increased along increasing latitude.

\section{Materials and Methods}

2.1. Experimental Design. One-year-old Scots pine (Pinus sylvestris L.) seedlings of two ecotypes from Kuhmo $\left(64^{\circ} \mathrm{N}\right.$; $200 \mathrm{~m}$ a.s.l.; 850-950 dd; $21 \mathrm{~h}$ day length during summer solstice) and Ranua $\left(66^{\circ} \mathrm{N} ; 150 \mathrm{~m}\right.$ a.s.l.; 950-1000 dd; $24 \mathrm{~h}$ day length during summer solstice), Northern Finland, were grown for three years (1999-2000) in transplantations of $0,1,2$ and $3^{\circ} \mathrm{N}$ towards north. Originally the investigation was planned as a 5-year project, but it had to be terminated prematurely due to Phacidium infestans infection in some seedling at two experimental sites (Kuusamo and Naruska). The browned seedlings were cut off and removed and the work was continued with non-infected individuals. Therefore, there were not enough seedlings to continue longer than 3 years.

The nursery grown seedlings were potted in $\varnothing 12 \mathrm{~cm}$ containers with open bottoms in 1997. The containers were filled with a mixture of sand, peat and raw forest humus $(1: 1: 1)$. The potted seedlings were transplanted into vicinities of the existing research stations or other well-man-aged areas. Each transplant garden consisted of 200 seedlings which were planted in a sandbed of approx. $5.5 \mathrm{~m}^{2}$ in size. The sandbed was composed of two layers, where the lower was a $20-\mathrm{cm}$-thick layer of sand and raw peat $(1: 1)$ and the upper layer consisted $10 \mathrm{~cm}$ of sand, into which the pots were dug. A datalogger (Hobo XT) was placed in the middle of the sandbed to record the temperature at $1 \mathrm{~h}$ intervals at the height of the shoot apices of the seedlings (adjusted according to elongation). The sandbed was surrounded by a wire-netting fence to prevent attacks by herbivores.

Each plot was watered with $100 \mathrm{~L}$ of tap water once a week during the growing season. In spring 1999, the seedlings were fertilized with $448 \mathrm{~kg} \mathrm{~N}^{-1}$ (Oulun Salpietari). The sites of latitude elevations for the ecotypes Kuhmo $\left(\mathrm{K}, 64^{\circ} \mathrm{N}\right)$ and Ranua $\left(\mathrm{R}, 66^{\circ} \mathrm{N}\right)$ were: (1) Kannus Research Station/Finnish Forest Research Institute (K/KAN, $\left.64^{\circ} \mathrm{N}\right)$, (2) University of Oulu (K/OUL, $65^{\circ} \mathrm{N}$ ), (3) Oulanka Biological Station/University of Oulu (K/KUU; R/KUU, $\left.66^{\circ} \mathrm{N}\right)$, (4) Transplant Garden in Salla, Naruska (K/NAR; R/NAR, $\left.67^{\circ} \mathrm{N}\right)$. The latter two sites were used for transplantation of the ecotype Ranua (R) (R/KUU, R/NAR): (5) Pallasjärvi Research Area/Finnish Forest Research Institute (R/PAL, $68^{\circ} \mathrm{N}$ ) and (6) Kilpisjärvi Biological Station/University of Helsinki $\left(\mathrm{R} / \mathrm{KIL}, 69^{\circ} \mathrm{N}\right)$. The map in Figure 1 shows the transplantations.

2.2. Sampling. The sampling procedure was performed twice a year: (1) In spring around the 20th May, when the snow had melted above the seedlings at each of the different latitude sites, (2) and at the autumnal equinox on the 23rd September. The sampling was performed only twice per year since the long-term (i.e., many years) experiment involved with several variables for the analyses was prioritized. Therefore, while a sampling design performed in few day intervals during time of the most rapid physiological changes in spring might be fascinated, it was left out as the snowmelts at different sites were unpredictable, and since it would have increased substantially the amount of work (which is 


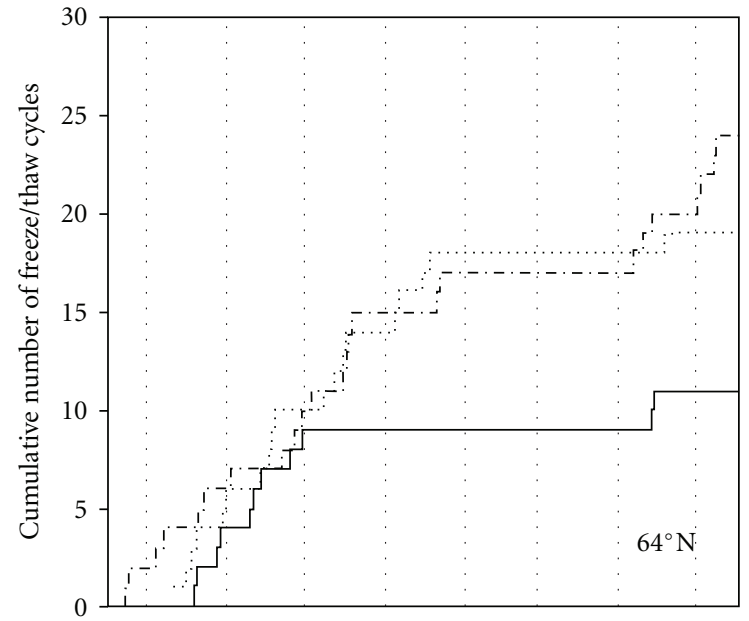

(a)

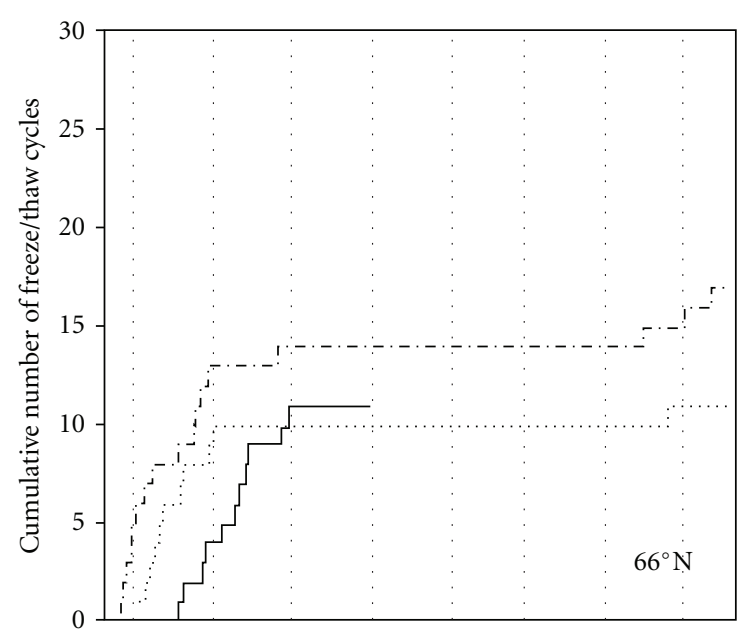

(c)

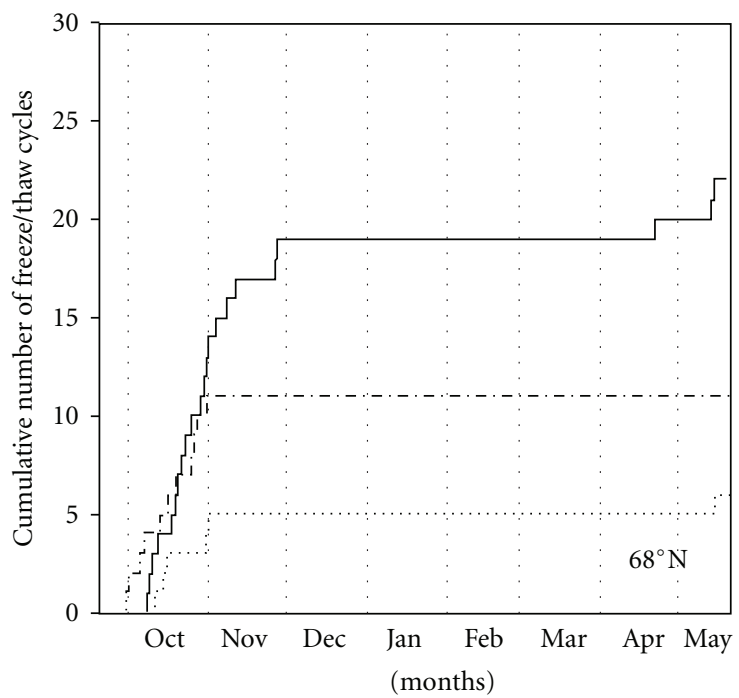

..... 1997-1998

-.. 1998-1999

- 1999-2000

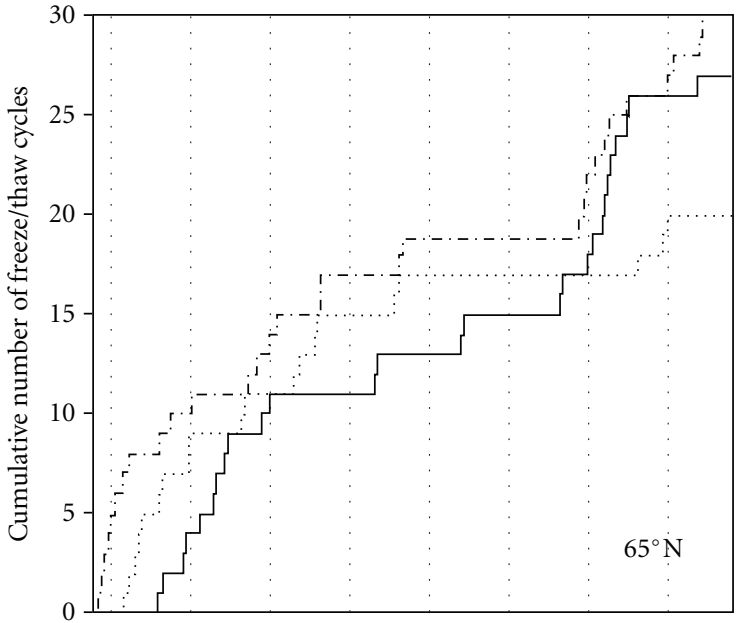

(b)

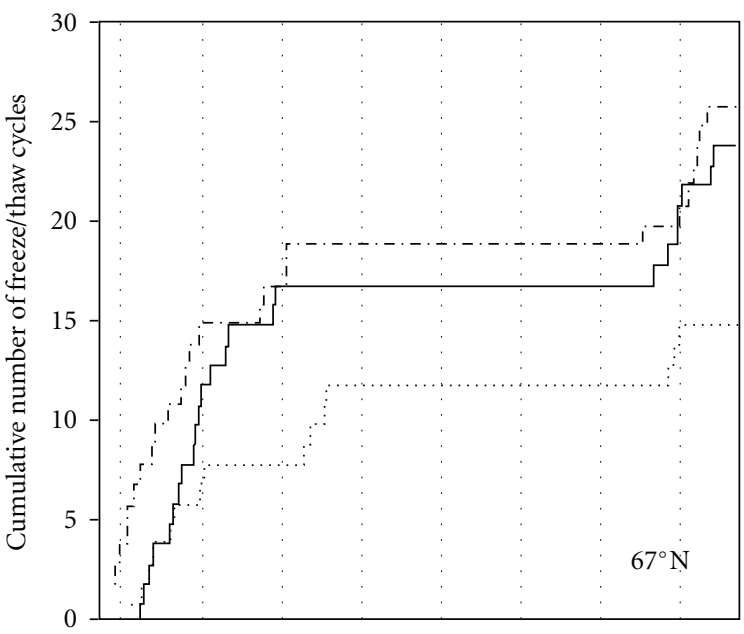

(d)

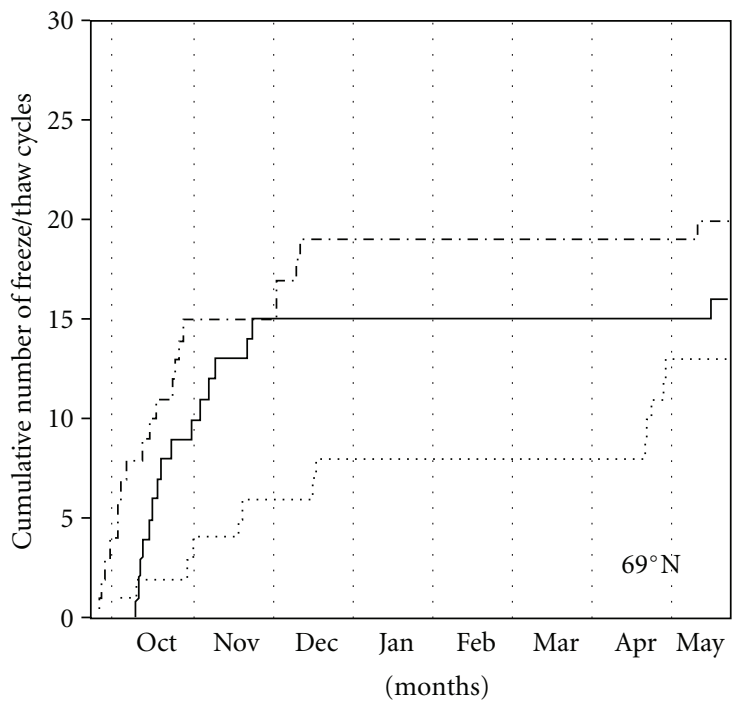

… 1997-1998

-.- 1998-1999

- 1999-2000

(e)

(f)

FIgURE 3: Cumulative number of freeze-thaw cycles at the transplantation sites at the seedling heights during 1998-2000. 
TABLE 1: Summary of comparisons between origin of the seedlings, and between the seasons of sampling in each analysed biological variable during the studied three-year period (1998-2000). The asterisks denote for statistically significant difference at: ${ }^{*} P<.05,{ }^{* *} P<.01$, and $* * * P<.001$. N.S.: nonsignificant.

\begin{tabular}{|c|c|c|c|c|}
\hline & \multicolumn{2}{|c|}{ Comparison between seasons } & \multicolumn{2}{|c|}{ Comparison between origin } \\
\hline & Spring versus & Autumn & $64^{\circ} \mathrm{N}$ versus & $66^{\circ} \mathrm{N}$ \\
\hline \multicolumn{5}{|l|}{ Variable } \\
\hline Shoot elongation & & & & $\downarrow * *$ \\
\hline $\mathrm{TN}(\%)$ & & $\downarrow * * *$ & & $\uparrow * * *$ \\
\hline Frost hardiness & & $\uparrow^{*}$ & & $\uparrow * * *$ \\
\hline Lipid peroxidation & & $\downarrow * * *$ & & $\downarrow *$ \\
\hline Glutathione reductase & & $\downarrow * * *$ & & N.S. \\
\hline Protein oxidation & & $\downarrow *$ & & N.S. \\
\hline
\end{tabular}

still huge). The idea was just to concentrate the periods after snowmelt before visible growth, and on the days with equal photoperiod in autumn. The mid-winter sampling was left out from the sampling set because of the variable changes in insulating snow cover between the latitude sites.

A set of 20 seedlings were randomly collected from the plots into Styrofoam boxes, filled up with crushed ice and transported to the University of Oulu within one day, where the elongation was measured (in autumn sampling). The seedlings were then divided into two groups, $0.2-1.0 \mathrm{~g}$ samples of needles of the main shoot's latest generation were weighed and stored in a deep freezer $\left(-70^{\circ} \mathrm{C}\right)$ after immersion into liquid nitrogen $\left(-196^{\circ} \mathrm{C}\right)$ for biochemical analysis. Needles from the other half of the seedlings were taken for a frost hardiness tests and total nitrogen content. In the latter case, the seedlings were oven dried at $+60^{\circ} \mathrm{C}$ for seven days.

2.3. Temperature Calculations. The raw temperature data recorded by the loggers were subjected to the following calculations. (1) Degree days (dd) were calculated based on the accumulated heat sum above the $+5^{\circ} \mathrm{C}$ threshold (Figure 2(a)). (2) The cumulative frost sum (i.e. below zero temperatures) was calculated using a similar principle with the exception of the threshold $\pm 0^{\circ} \mathrm{C}$ (Figure 2(b)). (3) The cumulative number of freeze-thaw cycles was obtained by counting each freezing episode after a temperature recording above $\pm 0^{\circ} \mathrm{C}$ (Figure 3).

2.4. Shoot Elongation. The elongation of the current year's main shoots were measured from the whole seedling set $(n=20)$ in autumn. The measurements were performed with a ruler at $\pm 1 \mathrm{~mm}$ accuracy. The terminal bud and the needles were excluded from the measurements.

2.5. Total Nitrogen Concentration (\%). $0.2 \mathrm{~g}$ of needles $(n=$ 5) were sampled for the analysis of total nitrogen (TN\%) concentration and dried at $+60^{\circ} \mathrm{C}$ for a week before grinding. TN\% was analyzed using an EA 1110 CNSH-0 (EA/NA 1110, Fison Instruments, Milano, Italy) automatic element analyzer.
2.6. Frost Hardiness. Frost hardiness was analyzed as $\mathrm{LT}_{50}$ (i.e. the temperature at $50 \%$ lethality of tissue) with the electrolyte leakage method described in detail elsewhere [1719]. Needles of four seedlings per treatment $(n=4)$ were exposed to five below-zero temperatures (i.e. $-5,-10,-20$, -40 and $-70^{\circ} \mathrm{C}$ ) in a rate-controlled freezer at the constant rates of $-6^{\circ} \mathrm{C} \mathrm{h}^{-1}$ and down to $-196^{\circ} \mathrm{C}$ by quick immersion in liquid nitrogen. The freeze-thaw procedure was followed by determination of viability of the needles by electrolyte leakage measurements and calculation of the $\mathrm{LT}_{50}$ by nonlinear function.

2.7. Lipid Peroxidation. Lipid peroxidation was analyzed as reported earlier [20]. $0.5 \mathrm{~g}$ of needles was homogenized in liquid nitrogen with a mortar and pestle. The homogenized tissue powder was suspended in $6 \mathrm{~mL}$ of $0.1 \%$ trichloroacetic acid (TCA) on ice and the suspension was centrifuged $10000 \mathrm{~g}$ for $5 \mathrm{~min} .1 \mathrm{~mL}$ of $20 \%$ (w/v) TCA containing $0.5 \%(\mathrm{w} / \mathrm{v})$ thiobarbituric acid (TBA) was added to a $1 \mathrm{ml}$ aliquot of the supernatant. After heating at $95^{\circ} \mathrm{C}$ for $30 \mathrm{~min}$, the mixture was quickly cooled in an ice-bath and centrifuged at $10000 \mathrm{~g}$ for $10 \mathrm{~min}$. The absorbance of the supernatant was read at $532 \mathrm{~nm}$ and the non-specific absorption at $600 \mathrm{~nm}$ was subtracted. The concentration of malondialdehyde (MDA) was calculated using the extinction coefficient of $155 \mathrm{mM}^{-1} \mathrm{~cm}^{-1}$.

2.8. Glutathione Reductase. Total glutathione reductase (GR; EC 1.6.4.2) activities in needles were measured as described previously [13]. $0.5 \mathrm{~g}$ of needles were ground in LN and following that in $5 \mathrm{ml} \mathrm{Na-phosphate} \mathrm{buffer} \mathrm{(} \mathrm{pH} 7.0$ ) containing $4 \%(\mathrm{w} / \mathrm{v})$ soluble polyvinylpyrrolidone (PVP) with a molecular weight of 360000 (Sigma), $2 \mathrm{mM}$ EDTA and $5 \mathrm{mM}$ DTT. The PVP was precipitated by adding a total of $1.5 \mathrm{ml}\left(\mathrm{NH}_{4}\right)_{2} \mathrm{SO}_{4}$ - saturated buffer (as the above buffer with PVP and DTT excluded) drop by drop. The extracts were left to precipitate for $15 \mathrm{~min}$, centrifuged at $15000 \mathrm{~g}$ for $3.5 \mathrm{~min}$ and the supernatant was stored at $-70^{\circ} \mathrm{C}$. All manipulations were performed at $4^{\circ} \mathrm{C}$. Immediately before the measurement of enzyme activity $3 \mathrm{ml}$ of extract was gel filtered with an Econo-Pac 10DG column (Bio-Rad) equilibrated with $50 \mathrm{mM}$ Na-phosphate buffer ( $\mathrm{pH}$ 7.0) containing $2 \mathrm{mM}$ EDTA. The GR-activity was measured at 


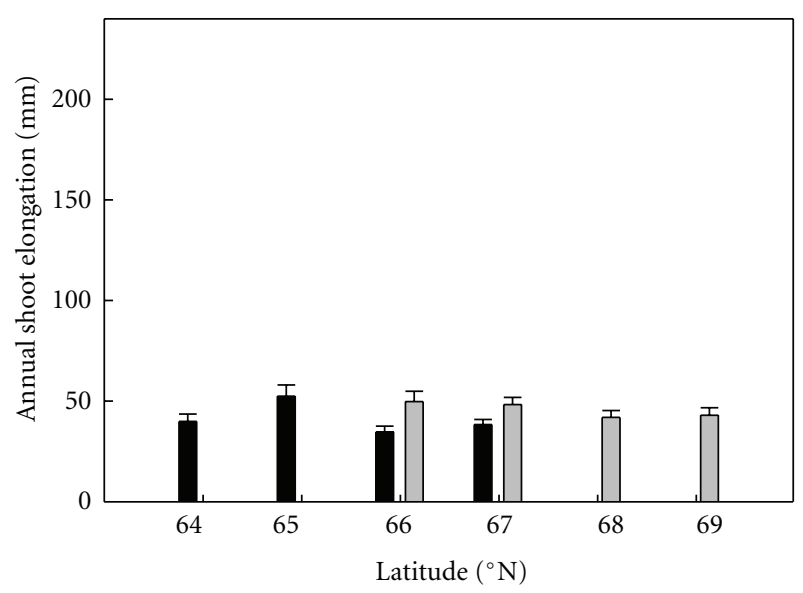

(a)

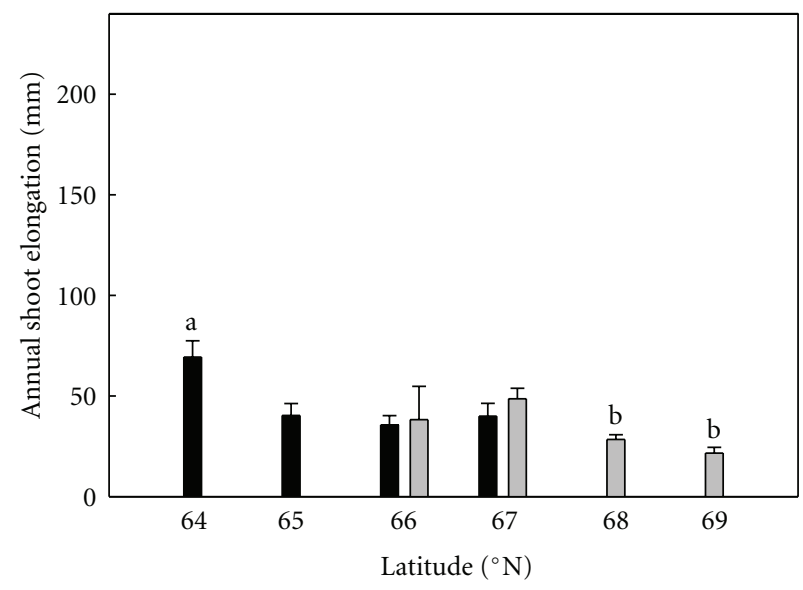

(b)

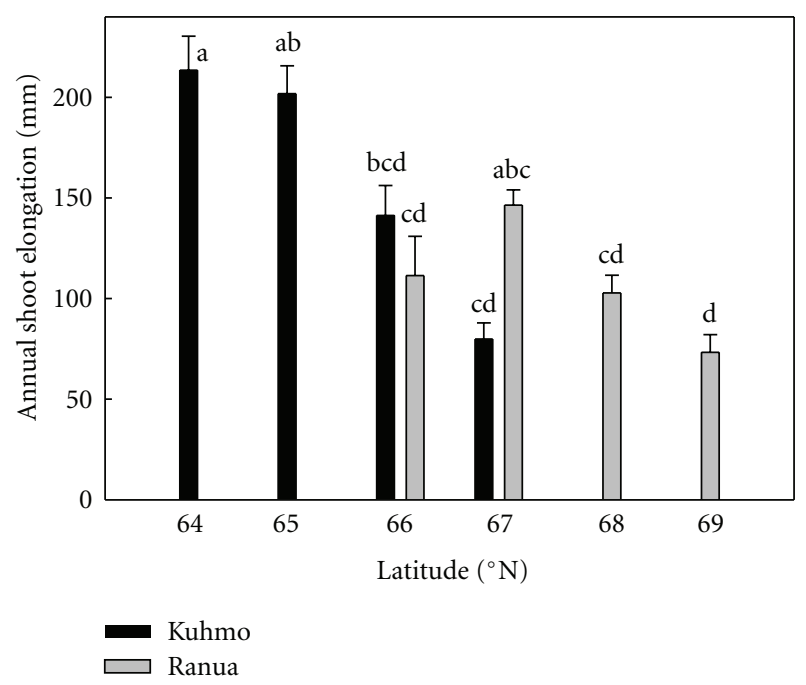

(c)

FIGURE 4: Annual shoot elongation of the Scots pine seedlings (mean \pm SE, $n=20$, except for $2000 n=20$ ) in (a) 1998, (b) 1999 and (c) 2000. Different letters indicate difference at $P<.05$.

$25^{\circ} \mathrm{C}$ as a function of the oxidation of $17 \mathrm{mM}$ NADPH by $1 \mathrm{mM}$ GSSG in a $25 \mathrm{mM}$ Na-phosphate buffer at $340 \mathrm{~nm}$.
Protein concentrations were determined according to Bradford [21].

2.9. Soluble and Oxidatively Modified Proteins. Protein carbonyl content as an index of protein oxidation was measured by reaction with 2.4-dinitrophenylhydrazine (2.4-DNPH) to form 2.4-diphenylhydrazone as described by Levine et al. $[22,23]$ and E. Taulavuori et al. [15]. After grinding $1 \mathrm{~g}$ of needle tissue in liquid nitrogen with mortar and pestle, proteins were extracted on ice in $10 \mathrm{ml}$ of extraction buffer ( $50 \mathrm{mM}$ sodium borate, $50 \mathrm{mM}$ ascorbic acid, $100 \mu \mathrm{M}$ DTT, $\mathrm{pH} 9.0$ ) containing following protease inhibitors: $2 \mu \mathrm{g} \mathrm{ml}$ leupeptin, $2 \mu \mathrm{g} \mathrm{ml}^{-1}$ antipain, $5 \mu \mathrm{g} \mathrm{ml}^{-1}$ aprotinin and $2 \mathrm{mM}$ PMSF. In addition, $0.5 \mathrm{~g}$ of insoluble polyvinylpolypyrrolidone (PVPP) hydrated in extraction buffer overnight was added to each sample during extraction. The homogenate was centrifuged at $25000 \mathrm{~g}$ at $4^{\circ} \mathrm{C}$ for $60 \mathrm{~min}$. The supernatants were stored at $-75^{\circ} \mathrm{C}$. After determination of soluble proteins [21], they were separated by SDS-PAGE on $10 \%$ gels. Each lane was loaded with $20 \mu \mathrm{g}$ of protein and the gels were run at $200 \mathrm{~V}$ (Bio-Rad Mini-PROTEAN 3 Cell apparatus) following the manufacturer's instructions. The gels were placed on a shaking platform and stained for $1 \mathrm{~h}$ with Coomassie Brilliant Blue R-250 (0,1\% CBB, 40\% methanol, and $10 \%$ acetic acid) and destained with the same solution without CBB. 2.4-DNPH-treated protein samples $(15 \mu \mathrm{g}$ of protein per lane) were resolved by SDS-PAGE on 10\% gels and electroblotted to Immunoblot-PVDF (Bio-Rad) with Mini Trans Blot Electrophoretic Transfer Cell (Bio-Rad) for $1 \mathrm{~h}$ at $100 \mathrm{~V}$ [24]. The membranes were blocked with Blotto ( $3 \% \mathrm{w} / \mathrm{v}$ non-fat dry milk in Tris-buffered saline). Oxidized proteins were probed with alkaline phosphatase-conjugated polyclonal anti-DNP antibody (Sigma) at 1: 4000 dilution. Goat-antirabbit IgG was used as a second antibody (dilution $1: 5000$ ), and the membrane was developed with an alkaline phosphatase conjugate substrate kit (Bio-Rad). The protein contents of gels and blots were quantified with Fluor-S image analyzer (Bio-Rad). The protein oxidation-ratio was calculated as follows: OD (optical density) of DNPH-treated protein/OD of non-DNPH-treated protein. An increase in the ratio indicates an increase in the relative proportion of oxidized proteins to nonoxidized soluble proteins.

2.10. Statistical Analyses. The bulk data pooled from the entire study period was tested for each variable on the comparison between harvest dates (spring versus autumn) and between ecotypes (Kuhmo versus Ranua) with independent sample T-test (SPSS 10.1). The effect of "treatment" (i.e. ecotype in the transplanted latitude) was tested with oneway ANOVA and subsequent post hoc test (Sheffe) per each sampling date. The ANOVA test included 8 treatments as (ecotype/latitude): (1) Kuhmo/Kannus, (2) Kuhmo/Oulu, (3) Kuhmo/Kuusamo, (4) Ranua/Kuusamo, (5) Kuhmo/ Naruska, (6) Ranua/Naruska, (7) Ranua/Pallasjärvi and (8) Ranua/Kilpisjärvi. The results from the $T$-test are summarized in Table 1, and the differences from ANOVA's post hoc comparison (Sheffe test, at $P<.05$ ) are indicated in the figures by different letters. 


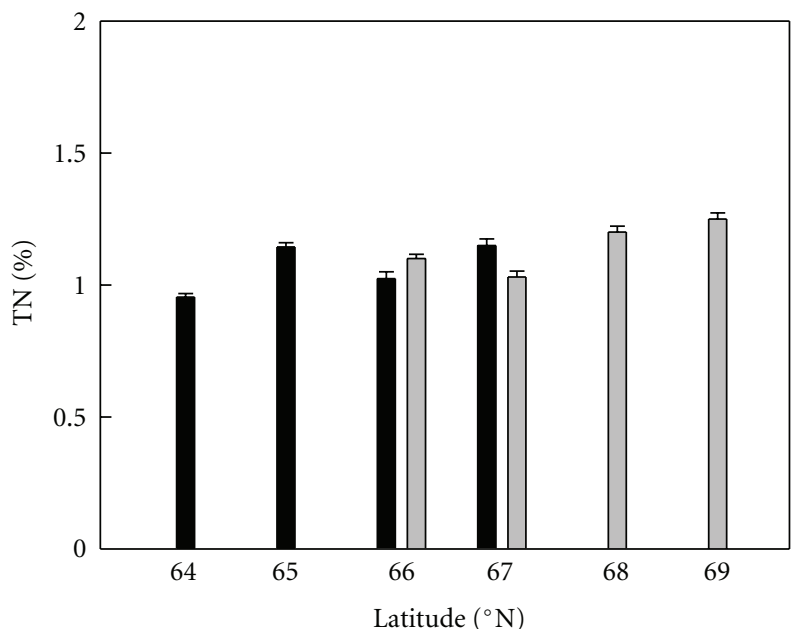

(a)

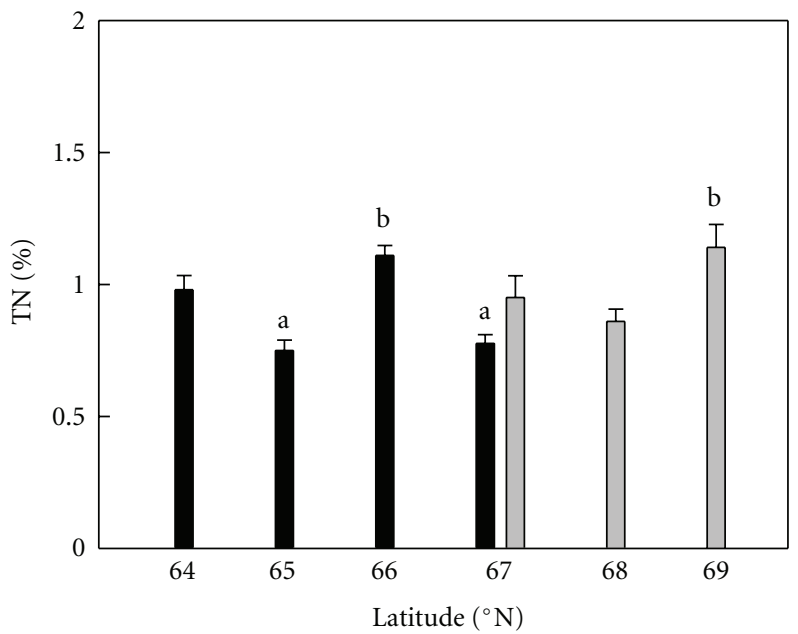

(c)

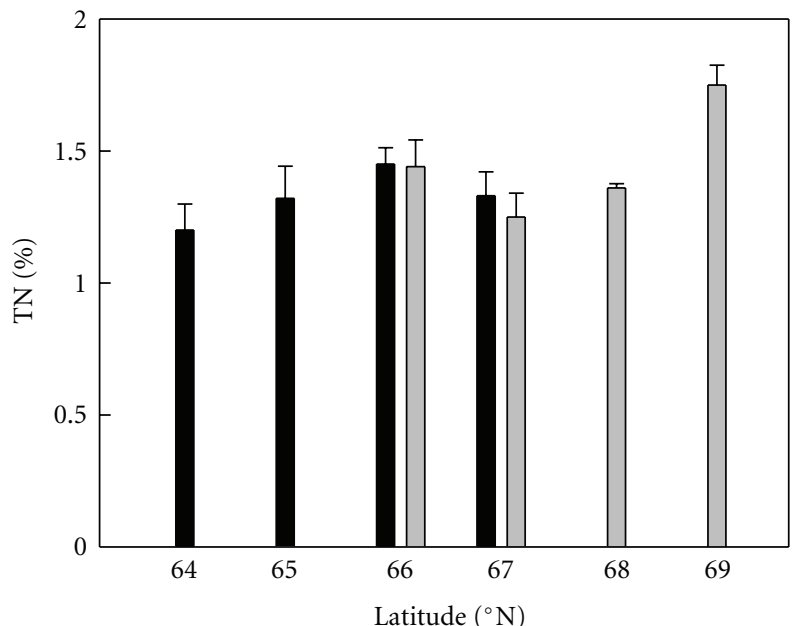

Kuhmo

Ranua

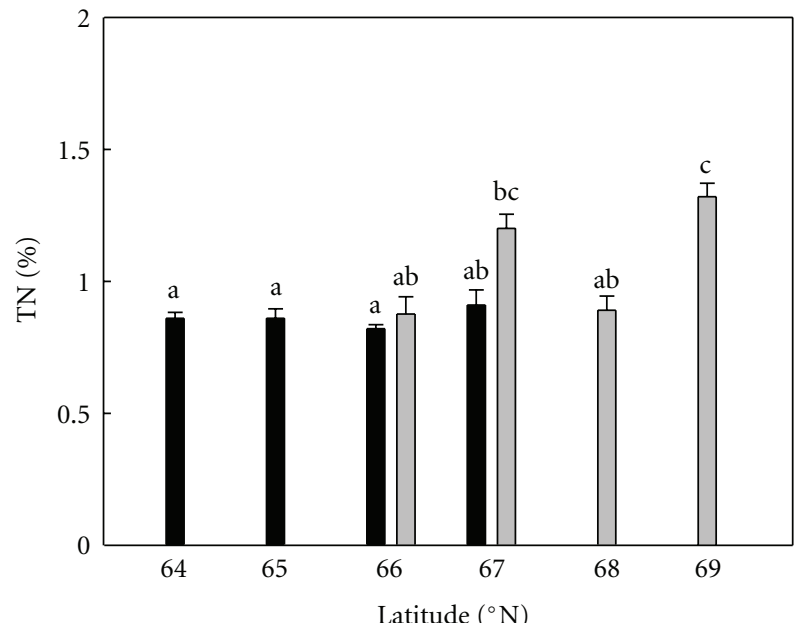

(b)

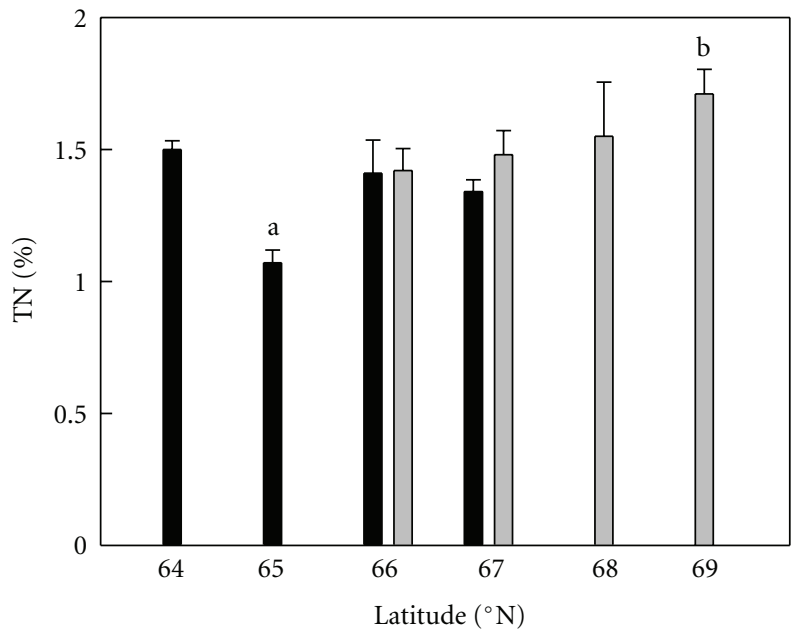

(d)

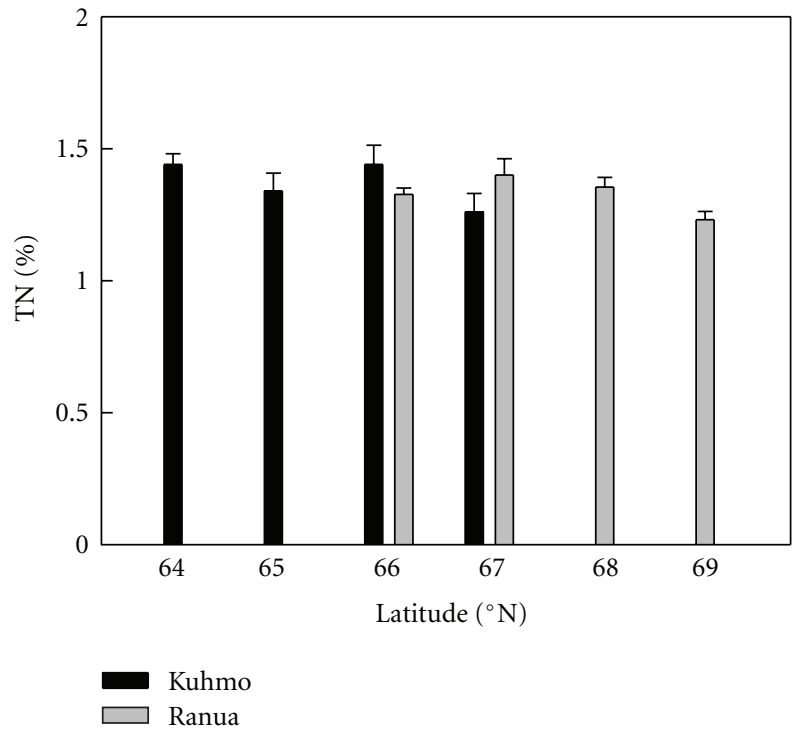

(f)

Figure 5: Total nitrogen concentrations (mean \pm SE, $n=7-8$ ) in (a) spring 1998, (b) autumn 1998, (c) spring 1999, (d) autumn 1999, (e) spring 2000, and (f) autumn 2000. Different letters indicate difference at $P<.05$. 


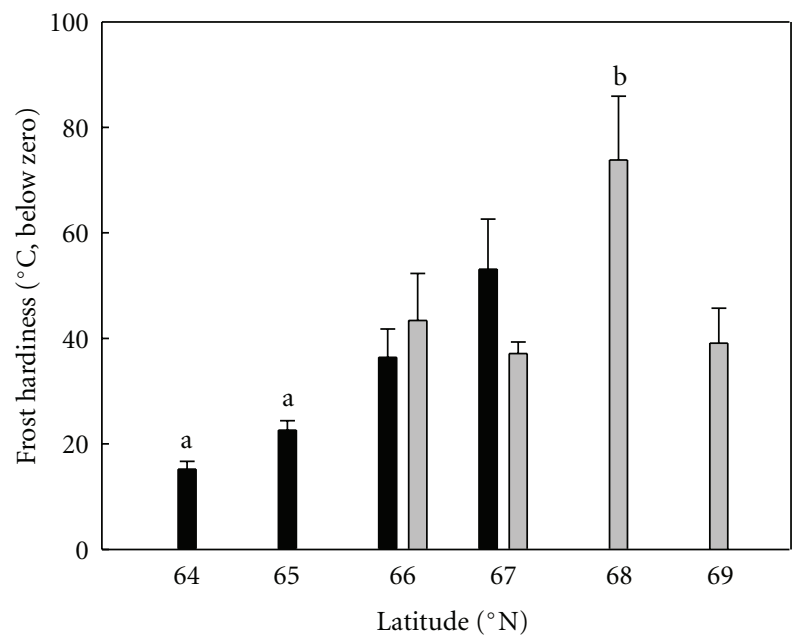

(a)

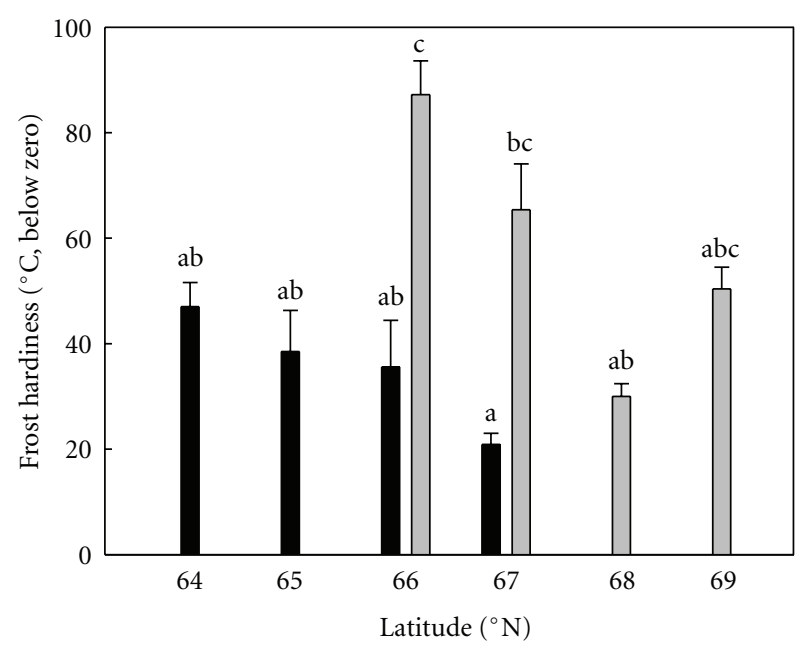

(c)

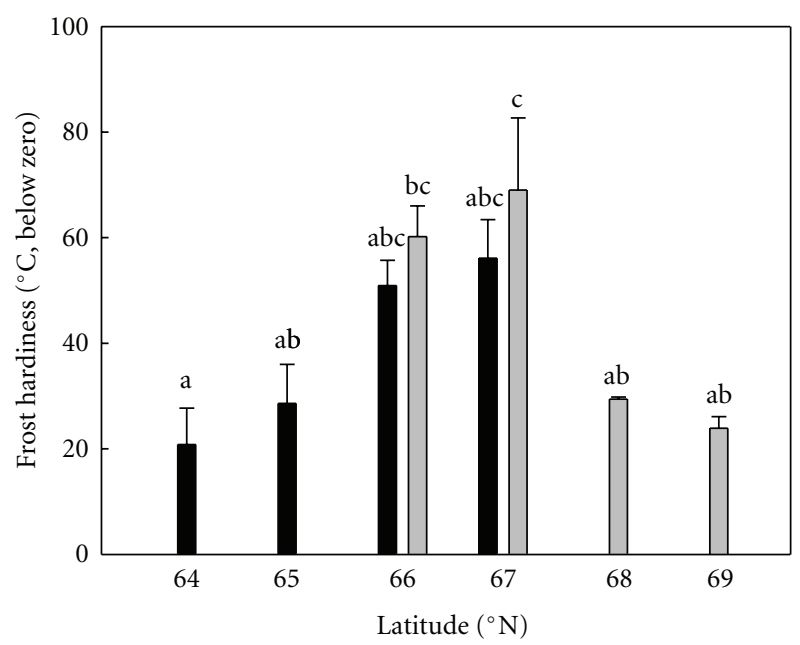

Kuhmo

$\square$ Ranua

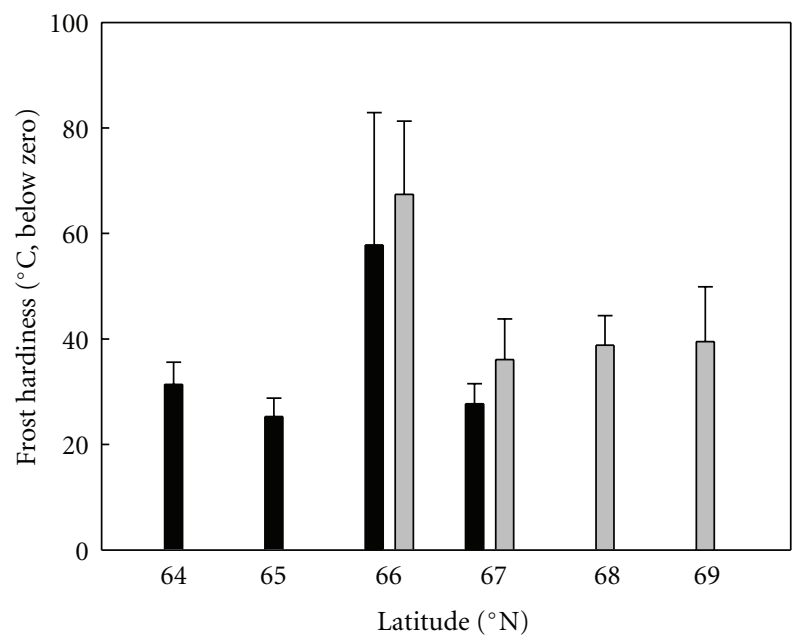

(b)

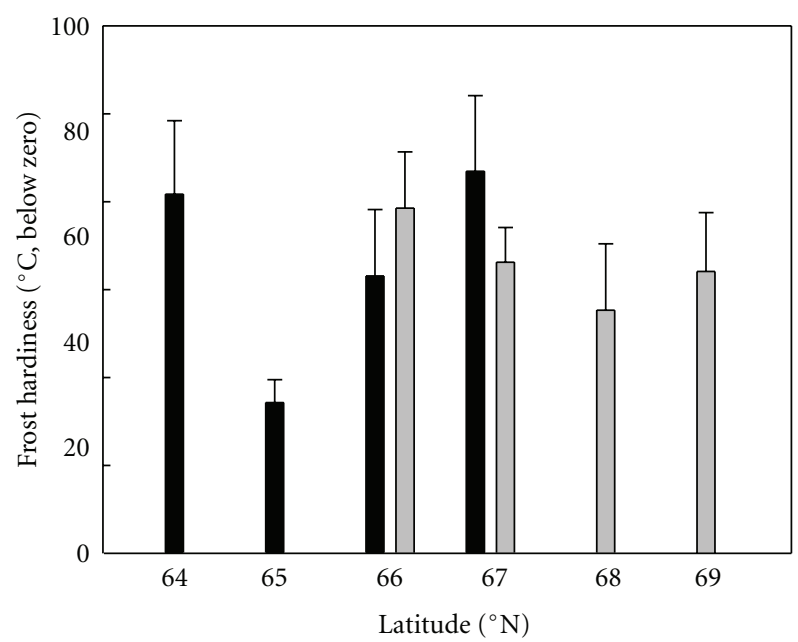

(d)

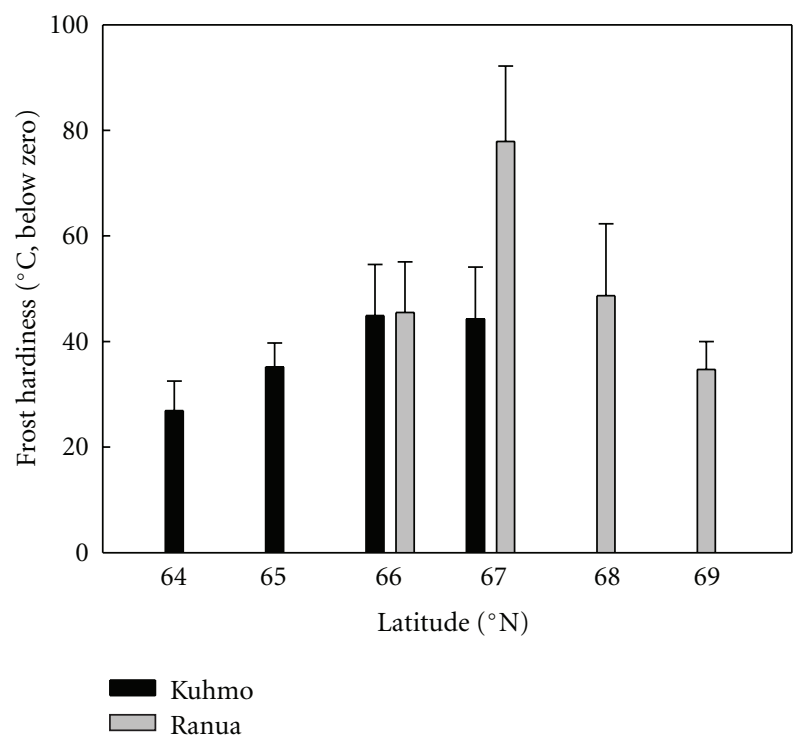

(f)

Figure 6: Frost hardiness (mean \pm SE, $n=6-8$ ), text otherwise as in Figure 5. 


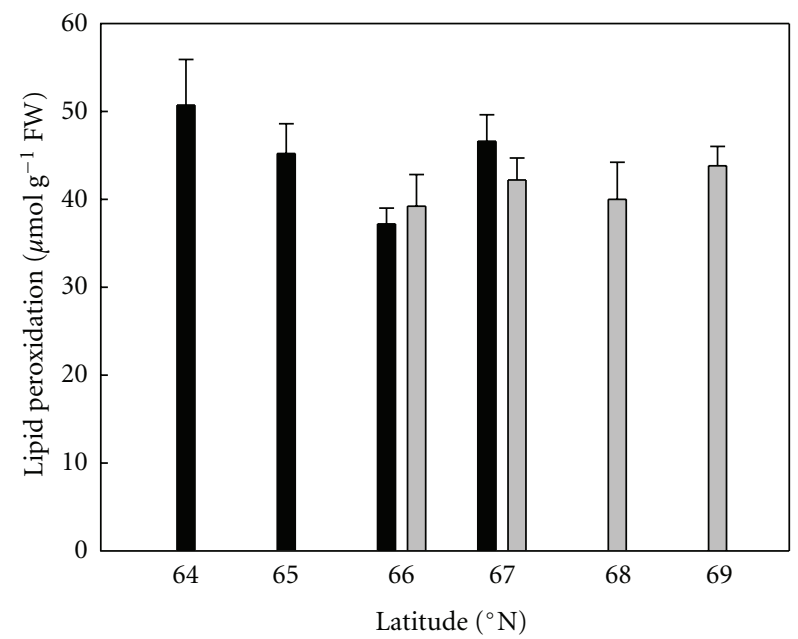

(a)

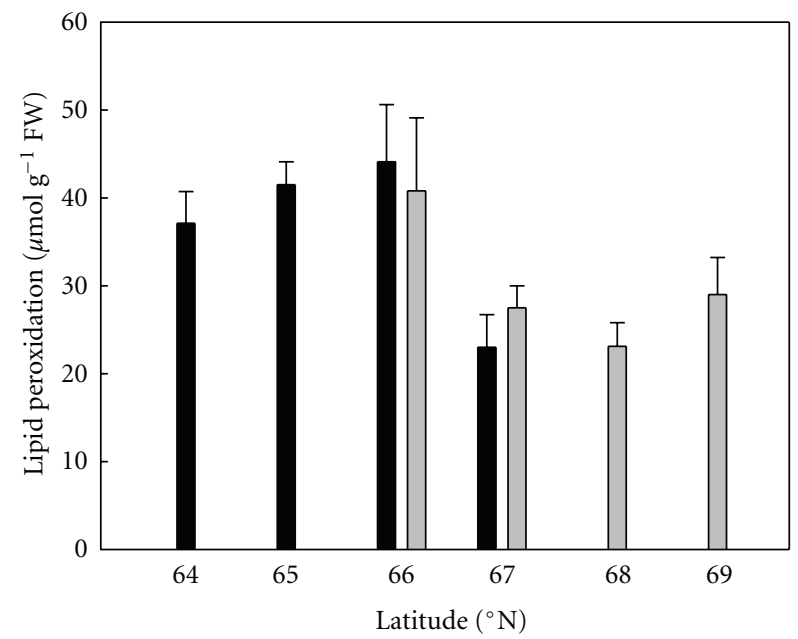

(c)

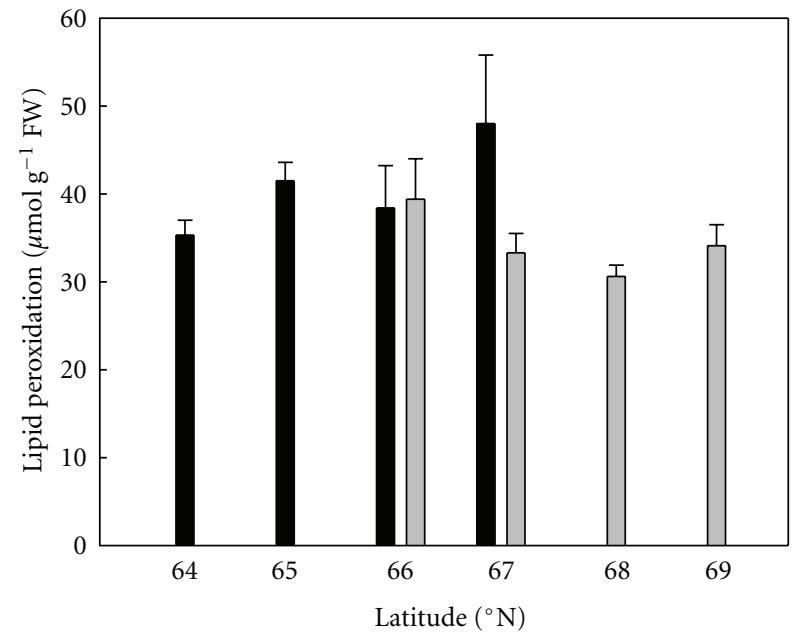

Kuhmo $\square$ Ranua

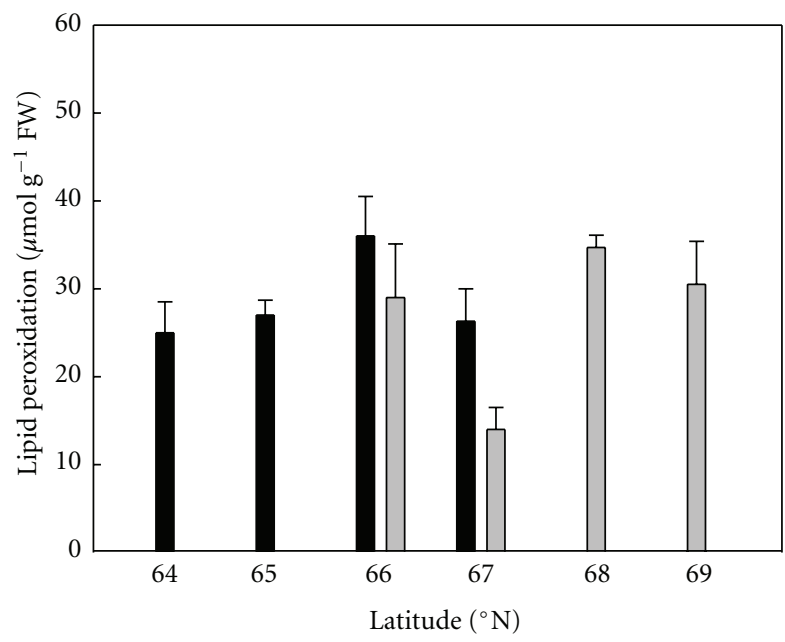

(b)

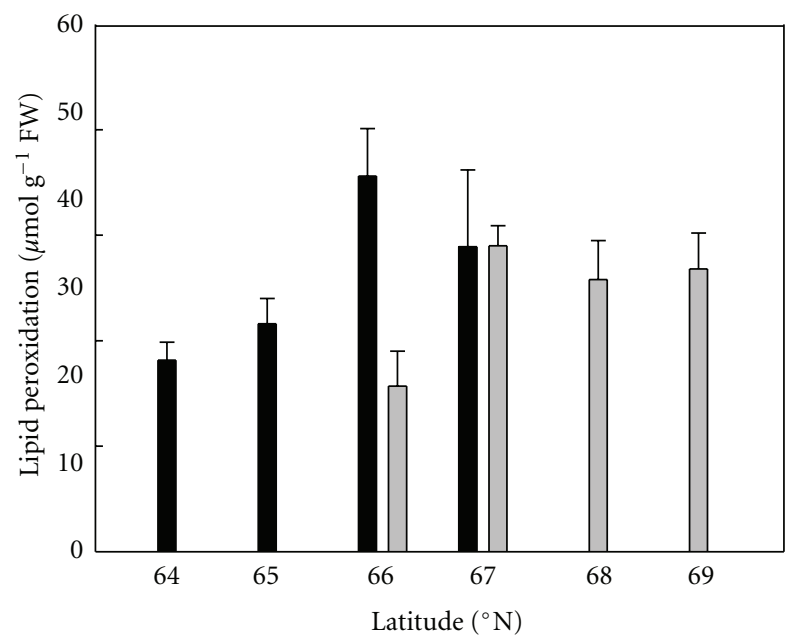

(d)

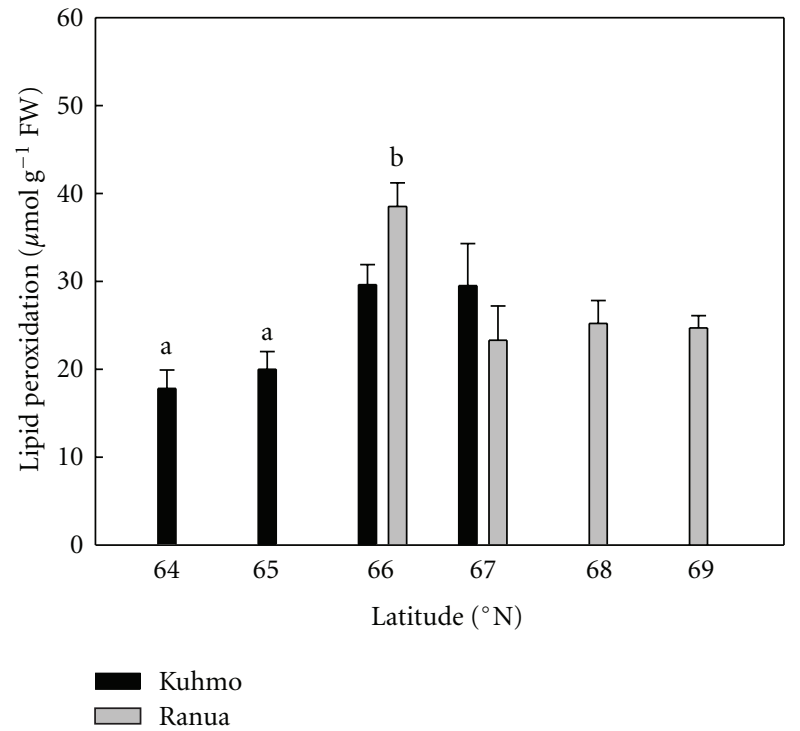

(f)

FIgURE 7: Lipid peroxidation (mean \pm SE, $n=3--7$ ), text otherwise as in Figure 5. 


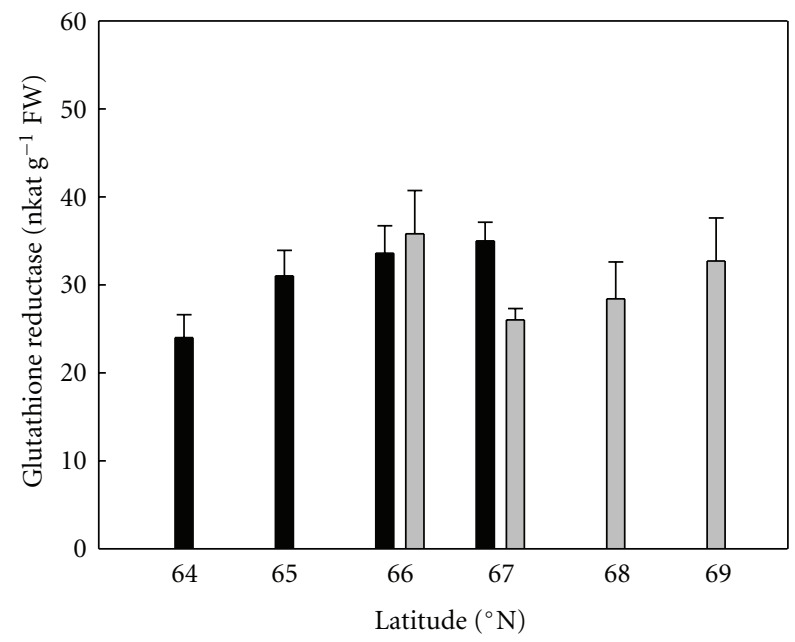

(a)

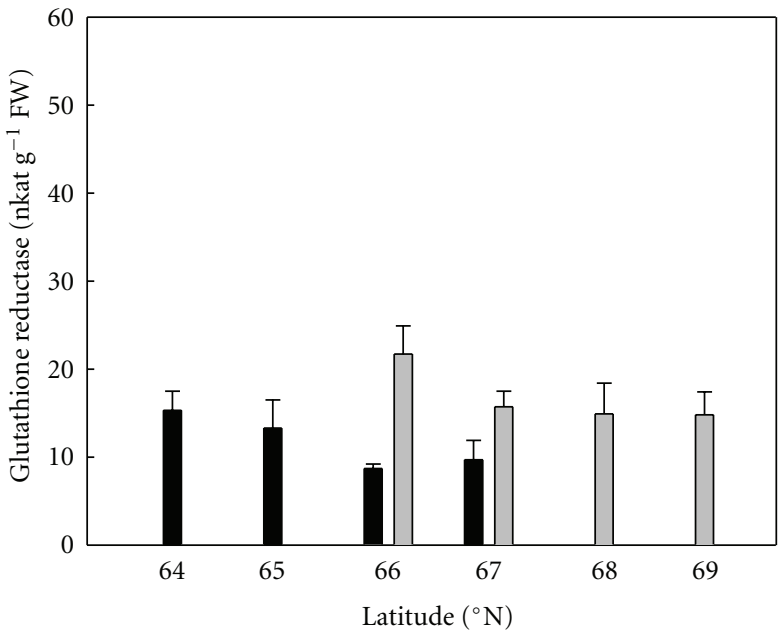

(c)

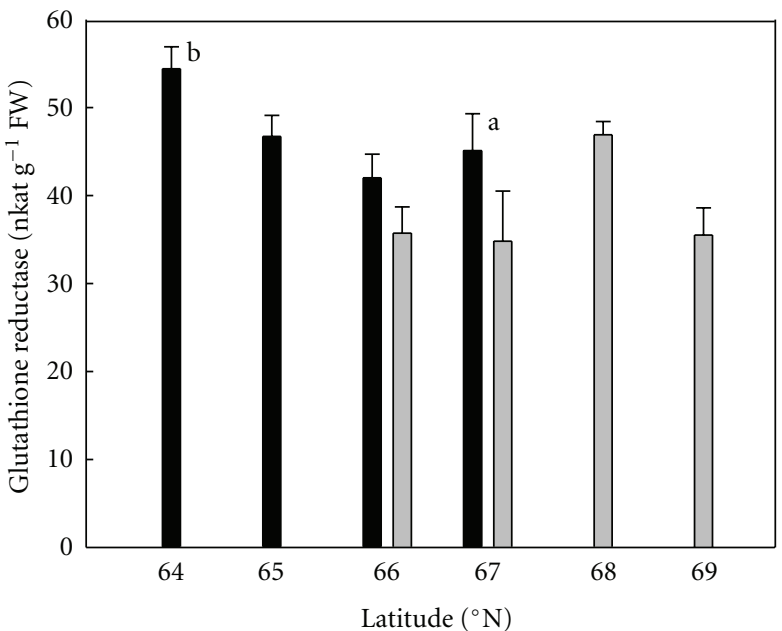

- Kuhmo $\square$ Ranua

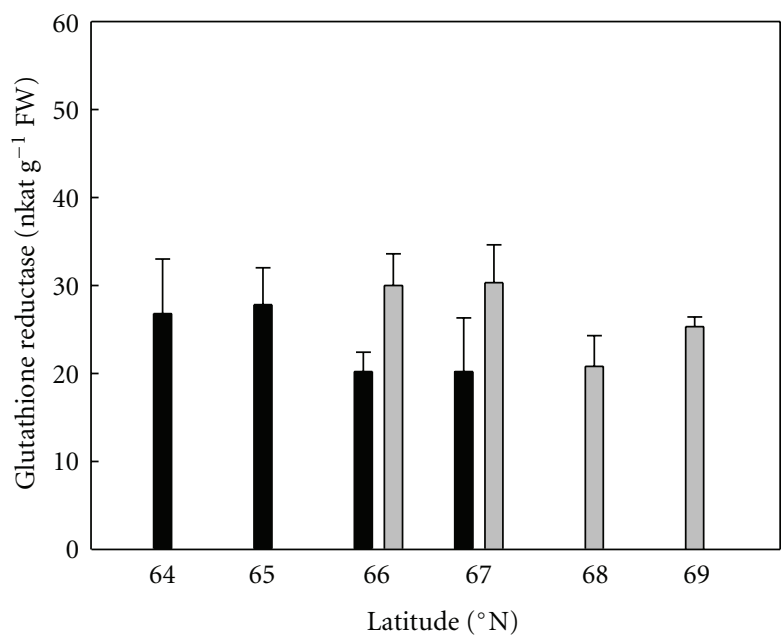

(b)

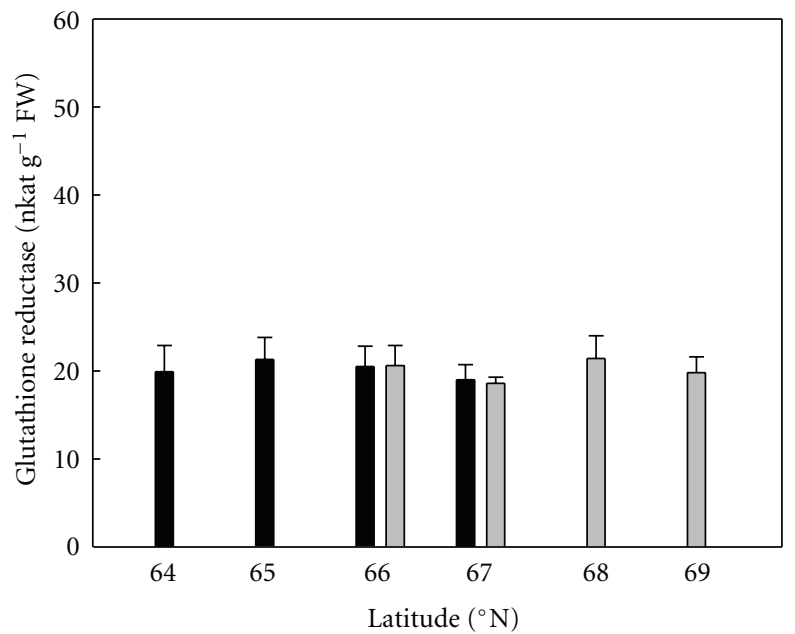

(d)

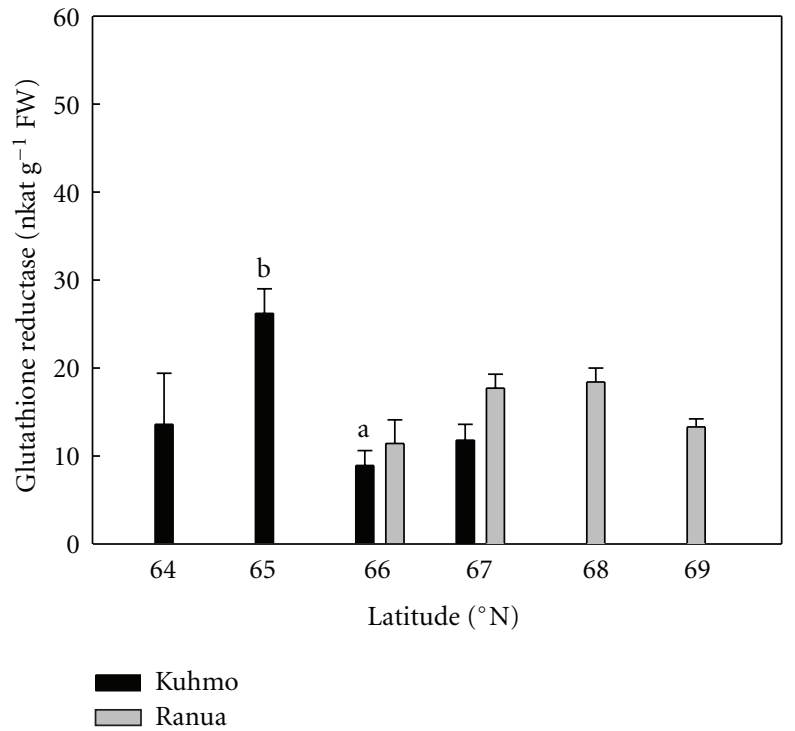

(f)

FIGURE 8: Glutathione reductase activity (mean \pm SE, $n=5--7$ ), text otherwise as in Figure 5. 


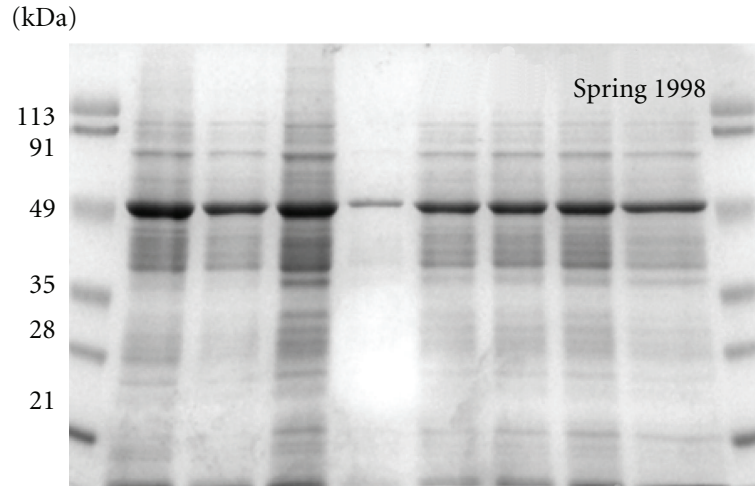

(a)

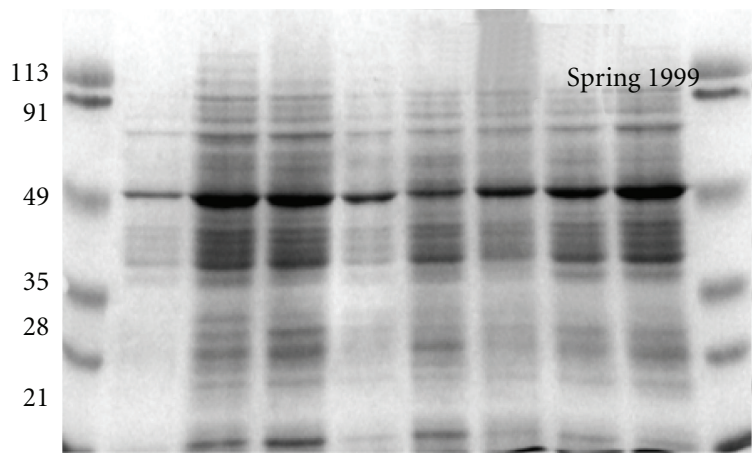

(c)

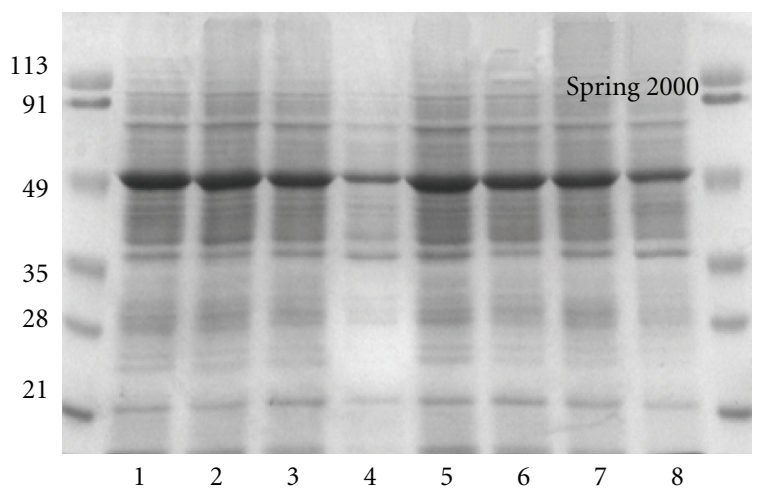

(e)

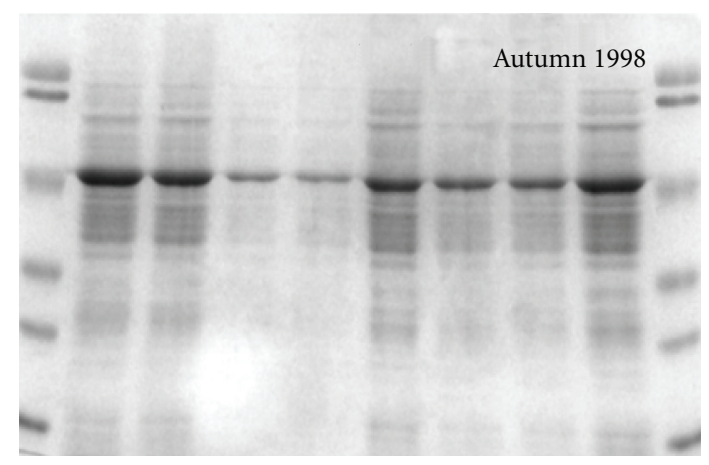

(b)

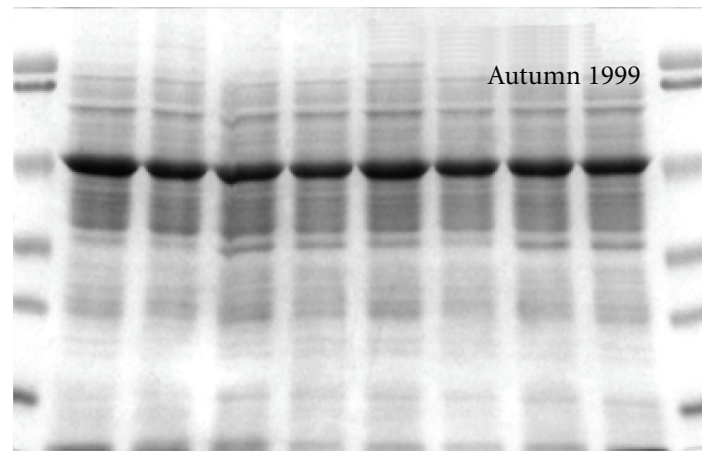

(d)

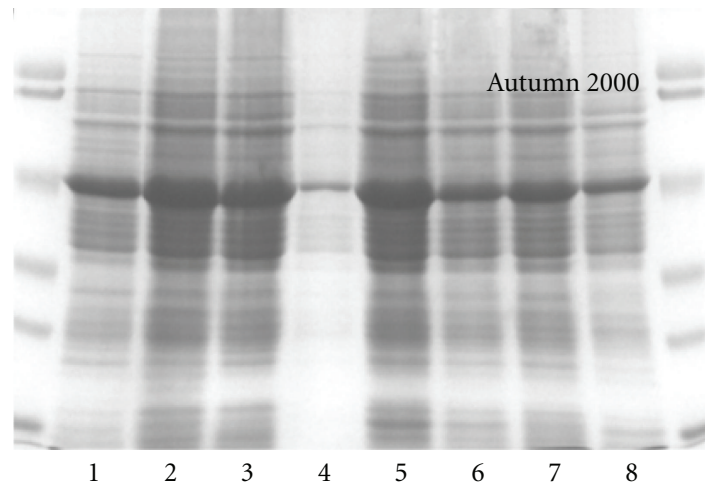

(f)

Figure 9: Soluble protein profiles: KDa (kilo Dalton), molecular weights of standards. Running numbers denote the ecotypes at their transplantation sites as follows: $1=\mathrm{K} / \mathrm{Kan}, 2=\mathrm{K} / \mathrm{Oul}, 3=\mathrm{K} / \mathrm{Kuu}, 4=\mathrm{K} / \mathrm{NAR}, 5=\mathrm{R} / \mathrm{Kuu}, 6=\mathrm{R} / \mathrm{Nar}, 7=\mathrm{R} / \mathrm{Pal}$, and $8=\mathrm{R} / \mathrm{Kil}$ (see text for more details).

\section{Results}

3.1. Temperature Experienced by Seedlings. The temperature sums (i.e., degree days) during the experimental period correlated negatively with the latitude sites, being highest $(>1000 \mathrm{dd})$ in Kannus $\left(64^{\circ} \mathrm{N}\right)$ and lowest $(<700 \mathrm{dd})$ in Kilpisjärvi $\left(69^{\circ} \mathrm{N}\right)$ (Figure $\left.2(\mathrm{a})\right)$. The temperature sums in the transplantation sites varied least $(<100 \mathrm{dd})$ in Kuusamo $\left(66^{\circ} \mathrm{N}\right)$ and most $(>300 \mathrm{dd})$ in Naruska $\left(68^{\circ} \mathrm{N}\right)$ within the three-year experimental period. The temperature sums were generally higher than their long-term averages, due to the open field conditions without any shading. The cumulative frost sum (Figure 2(b)) in winter did not correlate with the latitude because of the effect of the insulating snow cover. Higher frost sums (>1000) occurred in Oulu, Naruska and Kilpisjärvi and lower frost sums $(<1000)$ in Pallasjärvi, Kuusamo and Kannus. The winter of 1999 was generally cold, and included the Finnish record for cold temperature $\left(-51.5^{\circ} \mathrm{C}\right.$, Kittilä); the winter of 2000 was rather mild, having the lowest frost sums. The cumulative number of freezethaw cycles (Figure 3) also depended on the presence and thickness of the snow cover. Most of the other latitude sites (Kuusamo, Naruska, Pallasjärvi, and Kilpisjärvi) were characterized by freeze-thaw cycles, which had accumulated 
(kDa)

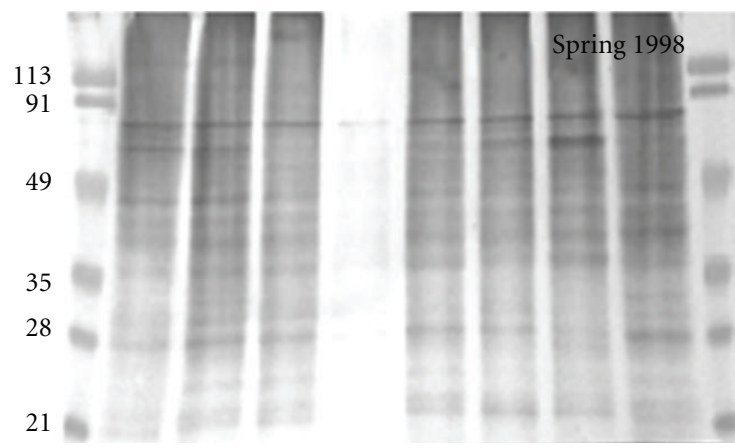

(a)

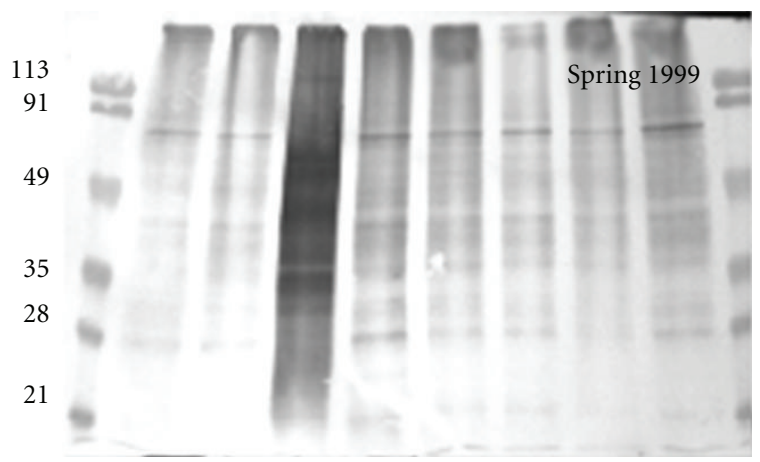

(c)

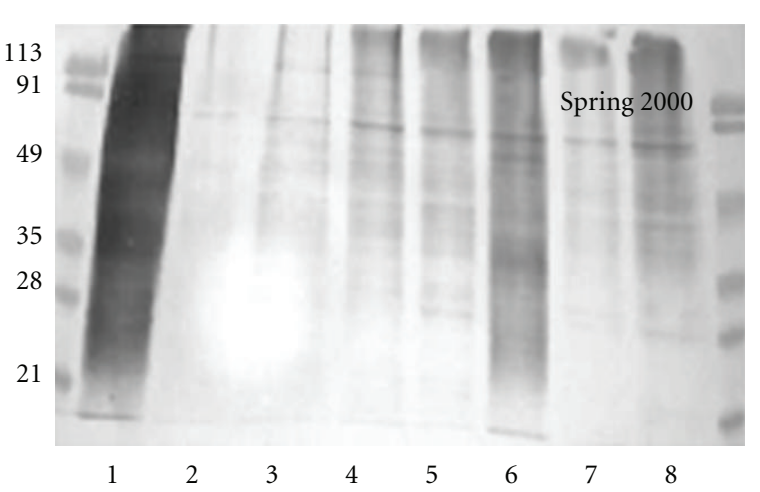

(e)

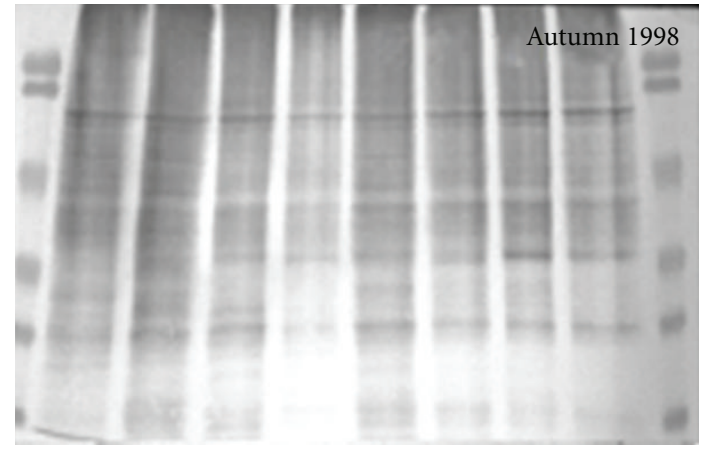

(b)

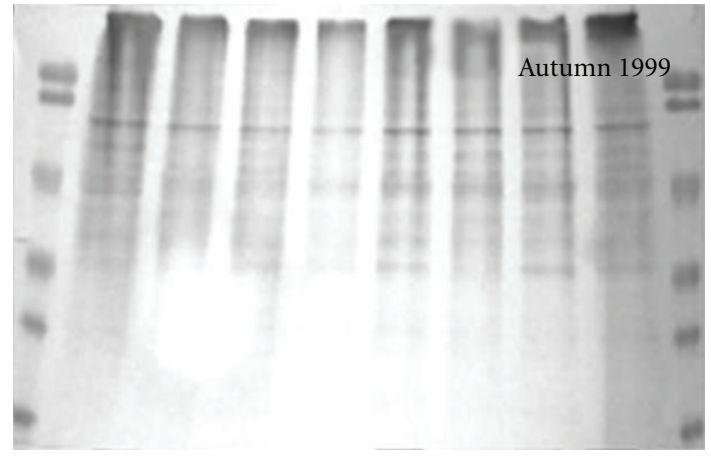

(d)

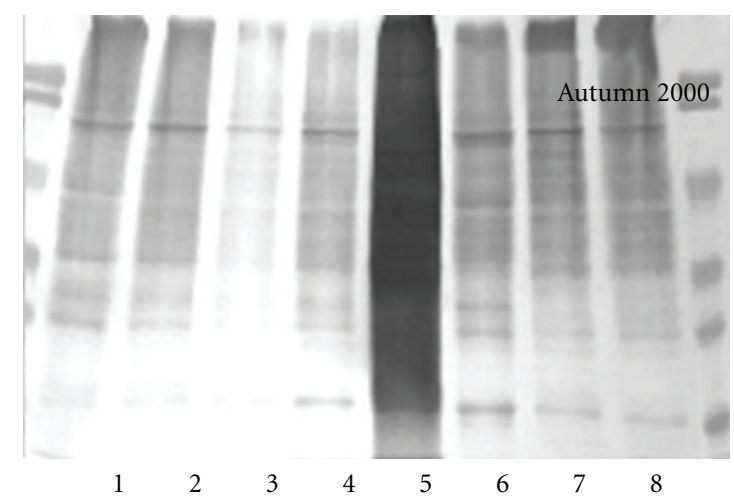

(f)

FIGURE 10: Oxidized protein profiles, text otherwise as in Figure 9.

early in the autumn and remained constant over five months due to snow. In Oulu the freeze-thaw cycles generally accumulated throughout the winter, indicating colder temperatures with thinner snow cover compared to Kannus.

3.2. Annual Shoot Elongation. Annual shoot elongation (Figure 4) was poor and equal during the first growing season 1998. In 1998 and 1999 the seedlings elongated only approx. $50 \mathrm{~mm}$ or less, but in 2000 the elongation varied approx. between 100 and $200 \mathrm{~mm}$. Elongation in the southern $64^{\circ} \mathrm{N}$ ecotype was more pronounced compared to the more northern $66^{\circ} \mathrm{N}$ ecotype $(P<.01)$ (Table 1$)$, especially during 2000. The effect of treatment (i.e., ecotype + latitude) $(P<$ .001 ) was evident during 2000 as the elongation pattern was almost exceptionally from high southern latitude recordings to low northern latitude recordings (Figure 4(c)).

3.3. Total Nitrogen Concentrations (TN \%). TN \% content (Figure 5) increased from approx. $1.0 \%$ to $1.5 \%$ between the spring and autumn 1999 (i.e. after the supplement fertilization), and remained higher throughout the rest of the experiment. The date of harvest affected the TN \% as the concentrations in autumn were significantly lower $(P<$ .001) (Table 1 ). The northern $66^{\circ} \mathrm{N}$ ecotype had significantly higher TN \% concentrations $(P<.001)$ (Table 1$)$. There were some differences at $P<.05$ between latitude sites also (Figures 5(b)-5(d)), and the general trend was that the accumulation of nitrogen was higher towards north. 
3.4. Frost Hardiness. Frost hardiness was generally higher in autumn $(P<.05)$, and the northern $66^{\circ} \mathrm{N}$ ecotype exhibited generally more pronounced $(P<.001)$ frost hardiness throughout the experiment (Table 1). The observed differences between the latitudes occurred only in the springtime analysis (Figures 6(a), 6(c), and 6(e)), indicating variable temperature conditions and a minor dependence on day length in spring.

3.5. Lipid Peroxidation. The lipid peroxidation (Figure 7) was significantly $(P<.001)$ higher in spring, and marginally higher in the southern $64^{\circ} \mathrm{N}$ ecotype (Table 1) No marked differences between the treatments were found, except for the last sampling in 2000: Lipid peroxidation was lowest in the southern transplantations of the southern ecotype.

3.6. Glutathione Reductase Activity. The GR activity (Figure 8) was higher in spring $(P<.001)$ compared to autumn values (Table 1). No general differences between the ecotypes were found. Also no marked trends between the treatments were observed.

3.7. Soluble and Oxidatively Modified Protein Profiles. Concentrations of the soluble proteins (Figure 9) in the needles at all experimental sites were the lowest in 1998 and the highest in autumn 1999. No difference in concentrations of soluble proteins was found between spring and autumn. The ecotype $64^{\circ} \mathrm{N}$ had marginally higher concentrations of soluble proteins. With only a few exceptions, the soluble proteins tended to decrease more towards higher latitudes in the southern $64^{\circ} \mathrm{N}$ ecotype, while not in the $66^{\circ} \mathrm{N}$ ecotype.

Concentrations of oxidized proteins (Figure 10) were generally highest in 1998. The amount of oxidation was significantly higher in spring $(P<.05)$. No differences between the ecotypes were found. No trends in relation to latitude were observed, except for the southern $64^{\circ} \mathrm{N}$ ecotype, at which concentrations of oxidized proteins increased towards the north in the spring of 1998 and 1999.

\section{Discussion}

Annual shoot elongation was first weak, but was then boosted by the extra fertilization in 1999, which resulted in an elevation of $\mathrm{N}$ concentration to an optimal level of around $1.5 \%$ (Figure 5(d)) in needles [25, 26]. The effect of added nitrogen on elongation was visible in following year's growth (Figure 4(c) as usually occurs (e.g., [26, 27]). After receiving the optimal $\mathrm{N}$ concentration level in 2000, the seedlings exhibited clear differences across the latitude gradient, indicating that the elongation increased towards southern latitudes. This is a logical result for two reasons: (1) elongation of Scots pine depends on temperatures of both current and previous years $[4,28]$, and (2) mean temperature drops approx. $1^{\circ} \mathrm{C}$ per latitude towards the north. The latter is consistent with degree days (Figure 2(a)), which decreased quite linearly from approximately $1200 \mathrm{dd}$ to $600 \mathrm{dd}$ between latitudes $64^{\circ} \mathrm{N}$ to $69^{\circ} \mathrm{N}$, respectively.
Increasing day length toward northern latitudes could potentially compensate for the reduced growth due to low temperature. However, it is obvious that the northern light environment may also affect elongation in another way. The relative proportion of blue light increases during the evening and night hours of the polar summer [3], which significantly reduces the elongation of Scots pine [29-31]. Thus, the effect of latitude on the elongation of Scots pine is most probably a result of a combination of temperature and light quality. Thus, the first hypothesis proved correct.

Sarala [32] proposed that northern populations are more sensitive to blue light compared to southern populations, since their elongation increases more significantly under removal of blue light. In addition, the northern populations are also more sensitive to other changes in the light quality (i.e. the ratio between red and far-red light) [33-36]. Accordingly, elongation of the $64^{\circ} \mathrm{N}$ ecotype was greater than elongation of the $66^{\circ} \mathrm{N}$ ecotype (Figure 4 ). On the other hand, elongation of the southern $\left(64^{\circ} \mathrm{N}\right)$ ecotype responded more significantly to the elevation of latitude. This could be explained by the fact that day length does not vary considerably in the studied latitudes $\left(66,67,68\right.$ and $\left.69^{\circ} \mathrm{N}\right)$ of the northern origin $\left(66^{\circ} \mathrm{N}\right)$ as the polar summer without sunset starts from the Arctic Circle $\left(67.5^{\circ} \mathrm{N}\right)$. This addresses an important question about population dynamics: Will the southern or northern ecotype survive better in a true competition, assuming that vegetation limits will shift towards north due to a warming climate [3]?

Weih and Karlsson [5] reported an increase in accumulation of $\mathrm{N}$ at high altitudes, obviously due to temperature conditions, which act as major growth-limiting factor [37]. The total nitrogen concentrations were consistently lower in the northern ecotype $\left(66^{\circ} \mathrm{N}\right)$ as it was transplanted to $2^{\circ} \mathrm{N}$ higher latitudes. In accordance with others $[16,38,39]$, the total nitrogen concentrations in spring were higher than the concentrations in autumn (Table 1), indicating that nitrogen of needles is utilized for stem elongation.

It is well known that plant frost hardiness may be reduced under excess nitrogen availability [40-43]. On the other hand, higher nitrogen concentration in an optimal range in autumn (Figures 5(b), 5(d), and 5(f)) may improve plant frost hardiness (e.g. [44-47]). Consistently, higher frost hardiness in the northern ecotype $\left(66^{\circ} \mathrm{N}\right)$ was accompanied by higher nitrogen concentrations (Table 1).

Frost hardiness develops in autumn in response to of extending nights and cooling weather, and fluctuates in winter mainly according to changes in temperature (e.g. [6, $18]$ ). Based on this, it was hypothesized that the development of frost hardiness of the seedlings in autumn is delayed along increasing latitude. As the observed differences in frost hardiness between the latitudes occurred only in the spring-time analyses, it is proposed that equal day length (i.e. sampling during autumnal equinox) in autumn was a dominant factor in relation to temperature and thereby equalized frost hardiness of Scots pine seedlings across the latitudinal gradient. This is the likely explanation since seedlings of Scots pine may be hardened even at $+20^{\circ} \mathrm{C}$ by only artificial extension of nights [19]. Thus, the hypothesis cannot be accepted, as no delay in frost hardening was 
observed. However, the hypothesis cannot be rejected either, as there is no data for the earlier period: The delay in the development of frost hardiness may have already occurred before the autumnal equinox.

On the other hand, the differences in frost hardiness between latitudes in spring strongly suggest the significance of temperature controlling, especially when considering the southern ecotype of $64^{\circ} \mathrm{N}$ in the spring of 1998 and 2000 (Figures 6(a) and 6(e)). However, there are also reports that extending day length could promote dehardening [48, 49], which could explain why frost hardiness at the highest two latitudes was rather low in the spring of 1999 and 2000. Moreover since this concerns the ecotype of the more northern origin it could also support the idea that northern populations are more sensitive to light [32-36].

Spring-time stress was evident as indicated by all three variables: higher lipid peroxidation, glutathione reductase activity and protein oxidation ratio (Table 1). The extent of lipid peroxidation increases in response to freezing stress $[7,11,50]$, and has varied from high to low levels between winter and spring, respectively $[9,10]$. Consistently, seasonal change in glutathione reductase has shown high winter to low summer activities $[8,12,13]$. Therefore, the oxidative stress state, shown by these variables with the increase in protein oxidations, put forward the idea that the period after snow melt and the subsequent increase in the amount of light is a stressful period for a conifer seedling. The increased amount of light in spring activates photosynthetic electron transport chain. Frozen ground prevents, however, the uptake of water and $\mathrm{CO}_{2}$ cannot thus penetrate needles due to the closed stomata which inhibits the carbon fixation. This leads to lack of $\mathrm{NADP}^{+}$normally acting as an electron acceptor and instead electrons end up to molecular oxygen which enhances the production of active oxygen species [51].

The increase in oxidative stress in spring is thus observable in enhanced antioxidant protection, which is consistent with the results of Karpinski et al. [52] on Scots pine seedlings. The fate of oxidized proteins is degradation (e.g. [15]), but as the concentrations of soluble proteins in spring were not lower as in autumn, it is assumed that new proteins related to protective metabolism were synthesized. Latitude had no remarkable effect on oxidative stress markers, except for the oxidized proteins that increased towards the north in the spring of 1998 and 1999 in the southern ecotype. This may indicate more pronounced stress the southern ecotype experiences in the north. The same holds true for the effect of ecotype with the exception of lipid peroxidation, which was marginally lower in the northern $66^{\circ} \mathrm{N}$ ecotype. Thus the hypothesis, according to which stress response increases along increasing latitude, is rejected.

In conclusion, not all results were as expected according to the hypotheses, but nevertheless they provide novel and interesting information about acclimation to higher latitudes. In light of the above results the effect of latitude on the elongation of Scots pine is most probably a result of a combination of temperature and light quality. The development of frost hardiness was not delayed due to higher latitude during the autumnal equinox, but the possibility of a delay before that remains open. No marked stress caused by transplantation to the north was observed. From the above results it is thus concluded, that southern ecotypes of Scots pine have the potential to adapt for migration driven by a warming climate. However, responses of more southern ecotypes should be studied in the future, since the migration distances may exceed even a thousand kilometers [1]. Furthermore, one should not ignore the possible effects of different photoperiod and light quality experienced by migrated vegetation at higher latitudes [3]. As for future prospects, transplantation should be tested in a condition where competition occurs between species and ecotypes.

\section{Acknowledgments}

Mrs. Päivi Räsänen is acknowledged for skilful technical assistance in the lab. The authors also thank Oulanka (University of Oulu) and Kilpisjärvi (University of Helsinki) Research Stations, and the Finnish Forest Research Institute (Kannus Research Station and Pallasjärvi Research Area), and the community of Salla for providing the research sites and staff for taking care of the experiment. The work was funded by the FIGARE program of the Academy of Finland, and the Thule Institute, University of Oulu.

\section{References}

[1] ACIA, Arctic Climate Impact Assessment, Cambridge University Press, 2005.

[2] IPCC, Climate Change 2001: The Scientific Basis Contribution of Working Group I to the Third Assessment Report of the Intergovernmental Panel on Climate Change (IPCC), Cambridge University Press, Cambridge, UK, 2001.

[3] K. Taulavuori, M. Sarala, and E. Taulavuori, "Growth responses of trees to Arctic light environment," Progress in Botany, vol. 71, pp. 157-168, 2010.

[4] O. Junttila and O. M. Heide, "Shoot and needle growth of Pinus sylvestris as related to temperature in Northern Fennoscandia," Forest Science, vol. 27, pp. 423-430, 1981.

[5] M. Wieh and P. S. Karlsson, "Growth response of altitudinal ecotypes of mountain birch to temperature and fertilisation," Oecologia, vol. 119, no. 1, pp. 16-23, 1999.

[6] A. Sakai and W. Larcher, "Frost survival of plants. Responses and adaptations to freezing stress," in Ecological Studies, W. D. Billings, F. Golley, O. L. Lange, J. S. Olson, and H. J. S., Eds., vol. 62, Springer, Berlin, Germany, 1987.

[7] E. E. Benson, P. T. Lynch, and J. Jones, "The detection of lipid peroxidation products in cryoprotected and frozen rice cells: consequences for post-thaw survival," Plant Science, vol. 85, no. 1, pp. 107-114, 1992.

[8] A. Polle and H. Rennenberg, "Field studies on Norway spruce trees at high altitudes: II. Defence systems against oxidative stress in needles," New Phytologist, vol. 121, no. 4, pp. 635-642, 1992.

[9] I. Cakmak, M. Atli, R. Kaya, H. Evliya, and H. Marschner, "Association of high light and zinc deficiency in cold-induced leaf chlorosis in grapefruit and mandarin trees," Journal of Plant Physiology, vol. 146, no. 3, pp. 355-360, 1995.

[10] K. M. J. Taulavuori, E. B. Taulavuori, O. Skre, J. Nilsen, B. Igeland, and K. M. Laine, "Dehardening of mountain birch (Betula pubescens ssp. czerepanovii) ecotypes at elevated winter 
temperatures," New Phytologist, vol. 162, no. 2, pp. 427-436, 2004.

[11] S. Bokhorst, J. W. Bjerke, M. P. Davey et al., "Impacts of extreme winter warming events on plant physiology in a subArctic heath community," Physiologia Plantarum, vol. 140, no. 2, pp. 128-140, 2010.

[12] E. Taulavuori, K. Taulavuori, and K. Laine, "Seasonality of glutathione dynamics in Scots pine and bilberry," Plant Biology, vol. 1, no. 2, pp. 187-191, 1999.

[13] E. Taulavuori, K. Taulavuori, T. Sarjala, and K. Laine, "Polyamines and glutathione metabolism in nitrogen fertilized Scots pine seedlings during cold hardening," Journal of Plant Physiology, vol. 154, no. 2, pp. 179-184, 1999.

[14] I. M. Møller and B. K. Kristensen, "Protein oxidation in plant mitochondria as a stress indicator," Photochemical and Photobiological Sciences, vol. 3, no. 8, pp. 730-735, 2004.

[15] E. Taulavuori, M. Tahkokorpi, K. Laine, and K. Taulavuori, "Drought tolerance of juvenile and mature leaves of a deciduous dwarf shrub Vaccinium myrtillus L. in a boreal environment," Protoplasma, vol. 241, no. 1, pp. 19-27, 2010.

[16] T. Näsholm and A. Ericsson, "Seasonal changes in amino acids, protein and total nitrogen in needles of Scots pine trees," Tree Physiology, vol. 6, pp. 267-682, 1990.

[17] K. Taulavuori, E. Taulavuori, A. Niinimaa, and K. Laine, "Frost resistance and $\mathrm{pH}$ of cell effusate in needles of artificially deacclimated Scots pine (Pinus sylvestris)," Physiologia Plantarum, vol. 96, no. 1, pp. 111-117, 1996.

[18] K. Taulavuori, A. Niinimaa, K. Laine, E. Taulavuori, and P. Lähdesmäki, "Modelling frost resistance of Scots pine seedlings using temperature, daylength and $\mathrm{pH}$ of cell effusate," Plant Ecology, vol. 133, no. 2, pp. 181-189, 1997.

[19] K. Taulavuori, E. Taulavuori, T. Sarjala et al., "In vivo Chlorophyll fluorescence is not always a good indicator of cold hardiness," Journal of Plant Physiology, vol. 157, no. 2, pp. 227 $229,2000$.

[20] E. Taulavuori, E. K. Hellström, K. Taulavuori, and K. Laine, "Comparison of two methods used to analyse lipid peroxidation from Vaccinium myrtillus (L.) during snow removal, reacclimation and cold acclimation," Journal of Experimental Botany, vol. 52, no. 365, pp. 2375-2380, 2001.

[21] M. M. Bradford, "A rapid and sensitive method for the quantitation of microgram quantities of protein utilizing the principle of protein dye binding," Analytical Biochemistry, vol. 72, no. 1-2, pp. 248-254, 1976.

[22] R. L. Levine, D. Garland, C. N. Oliver et al., "Determination of carbonyl content in oxidatively modified proteins," Methods in Enzymology, vol. 186, pp. 464-478, 1990.

[23] R. L. Levine, J. A. Williams, E. R. Stadtman, and E. Shacter, "Carbonyl assays for determination of oxidatively modified proteins," Methods in Enzymology, vol. 233, pp. 346-357, 1994.

[24] E. Harlow and D. Lane, Antibodies. A laboratory Manual, Cold Spring Harbor La-boratory, 1988.

[25] T. Ingestad and A.-B. Lund, "Nitrogen stress in birch seedlings," Physiologia Plantarum, vol. 45, pp. 137-148, 1979.

[26] L. Dewald, T. L. White, and M. L. Duryea, "Growth and phenology of seedlings of four contrasting slash pine families in ten nitrogen regimes," Tree Physiology, vol. 11, no. 3, pp. 255-269, 1992.

[27] S. Kontunen-Soppela, K. Taulavuori, E. Taulavuori, P. Lähdesmäki, and K. Laine, "Soluble proteins and dehydrins in nitrogen-fertilized Scots pine seedlings during deacclimation and the onset of growth," Physiologia Plantarum, vol. 109, no. 4, pp. 404-409, 2000.
[28] O. Junttila, "Effects of temperature on shoot growth in northern provenances of Pinus sylvestris L," Tree Physiology, vol. 1, pp. 185-192, 1986.

[29] K. Taulavuori, M. Sarala, J. Karhu et al., "Elongation of scots pine seedlings under blue light depletion," Silva Fennica, vol. 39, no. 1, pp. 131-136, 2005.

[30] M. Sarala, K. Taulavuori, E. Taulavuori, J. Karhu, and K. Laine, "Elongation of Scots pine seedlings under blue light depletion is independent of etiolation," Environmental and Experimental Botany, vol. 60, no. 3, pp. 340-343, 2007.

[31] M. Sarala, E. Taulavuori, J. Karhu et al., "Improved elongation of Scots pine seedlings under blue light depletion is not dependent on resource acquisition," Functional Plant Biology, vol. 36, no. 8, pp. 742-751, 2009.

[32] M. Sarala, "Elongation of Scots pine seedlings under blue light depletion," Acta Universitatis Ouluensis A. In press.

[33] D. H. Clapham, I. Dormling, I. Ekberg, G. Eriksson, M. Qamaruddin, and . Vince-Prue, "Latitudinal cline of requirement for far-red light for the photoperiodic control of budset and extension growth in Picea abies (Norway spruce)," Physiologia Plantarum, vol. 102, no. 1, pp. 71-78, 1998.

[34] D. H. Clapham, I. Ekberg, G. Eriksson, L. Norell, and D. VincePrue, "Requirement for far-red light to maintain secondary needle extension growth in northern but not southern populations of Pinus sylvestris (Scots pine)," Physiologia Plantarum, vol. 114, no. 2, pp. 207-212, 2002.

[35] H. K. Stenøien, C. B. Fenster, H. Kuittinen, and O. Savolainen, "Quantifying latitudinal clines to light responses in natural populations of Arabidopsis thaliana (Brassicaceae)," American Journal of Botany, vol. 89, no. 10, pp. 1604-1608, 2002.

[36] J. A. Mølmann, O. Junttila, $\varnothing$. Johnsen, and J. E. Olsen, "Effects of red, far-red and blue light in maintaining growth in latitudinal populations of Norway spruce (Picea abies)," Plant, Cell and Environment, vol. 29, no. 2, pp. 166-172, 2006.

[37] CH. Körner, "The nutritional status of plants from high altitudes-a worldwide comparison," Oecologia, vol. 81, no. 3, pp. 379-391, 1989.

[38] K. Gezelius, "Free amino acids and total nitrogen during shoot development in Scots pine seedlings," Physiologia Plantarum, vol. 67, no. 4, pp. 435-441, 1986.

[39] H.-S. Hellergren, "Temporal variation in nutrient concentrations of Pinus sylvestris seedlings," Scandinavian Journal of Forest Research, vol. 5, pp. 177-193, 1990.

[40] L. Christersson, "Frost hardiness development in Pinus sylvestris L. seedlings at dif-ferent levels of potassium and calcium fertilization," Canadian Journal of Forest Research, vol. 19, pp. 1037-1043, 1975.

[41] A. Aronson, "Frost hardiness in Scots pine (Pinus sylvestris L.)," Studia Forestalia Suecica, vol. 155, pp. 1-27, 1980.

[42] J. Hellergren, "Frost hardiness development in Pinus silvestris seedlings in response to fertilization," Physiologia Plantarum, vol. 52, pp. 297-301, 1981.

[43] J. N. Cape, I.D. Leith, and D. Fowler, "Sulphate and ammonium in mist impair the frost hardening of red spruce seedlings," New Phytologist, vol. 118, pp. 119-126, 1991.

[44] S. J. M. Caporn, M. Risager, and J. A. Lee, "Effect of nitrogen supply on frost hardiness in Calluna vulgaris (L.) Hull," New Phytologist, vol. 128, no. 3, pp. 461-468, 1994.

[45] E. Taulavuori, K. Taulavuori, K. Laine, T. Pakonen, and E. Saari, "Winter hardening and glutathione status in the bilberry (Vaccinium myrtillus) in response to trace gases $\left(\mathrm{CO}_{2}, \mathrm{O}_{3}\right)$ and nitrogen fertilization," Physiologia Plantarum, vol. 101, no. 1, pp. 192-198, 1997. 
[46] K. Taulavuori, E. Taulavuori, A. Niinimaa, and K. Laine, "Acceleration of frost hardening in Vaccinium vitis-idaea by nitrogen fertilization," Oecologia, vol. 127, no. 3, pp. 321-323, 2001.

[47] L. J. Sheppard, U. Rosengren, and B. A. Emmett, "Do nitrogen additions change the sensitivity of detached shoots from sitka and norway spruce to freezing temperatures? Evidence from three field manipulation studies," Scandinavian Journal of Forest Research, vol. 18, no. 6, pp. 487-498, 2003.

[48] I. Leinonen, T. Repo, and H. Hänninen, "Changing environmental effects on frost hardiness of scots pine during dehardening," Annals of Botany, vol. 79, no. 2, pp. 133-138, 1997.

[49] E. H. Beck, R. Heim, and J. Hansen, "Plant resistance to cold stress: mechanisms and environmental signals triggering frost hardening and dehardening," Journal of Biosciences, vol. 29, no. 4, pp. 449-459, 2004.

[50] A. Polle, W. Kröniger, and H. Rennenberg, "Seasonal fluctuations of ascorbate-related enzymes: acute and delayed effects of late frost in spring on antioxidative systems in needles of norway spruce (Picea abies L.)," Plant and Cell Physiology, vol. 37, no. 6, pp. 717-725, 1996.

[51] C. H. Foyer, M. Lelandais, and K. J. Kunert, "Photooxidative stress in plants," Physiologia Plantarum, vol. 92, no. 4, pp. 696717, 1994.

[52] S. Karpinski, G. Wingsle, B. Karpinska, and J. E. Hallgren, "Molecular responses to photooxidative stress in Pinus sylvestris (L.). II.Differential expression of CuZn-superoxide dismutases and glutathione reductase," Plant Physiology, vol. 103, no. 4, pp. 1385-1391, 1993. 

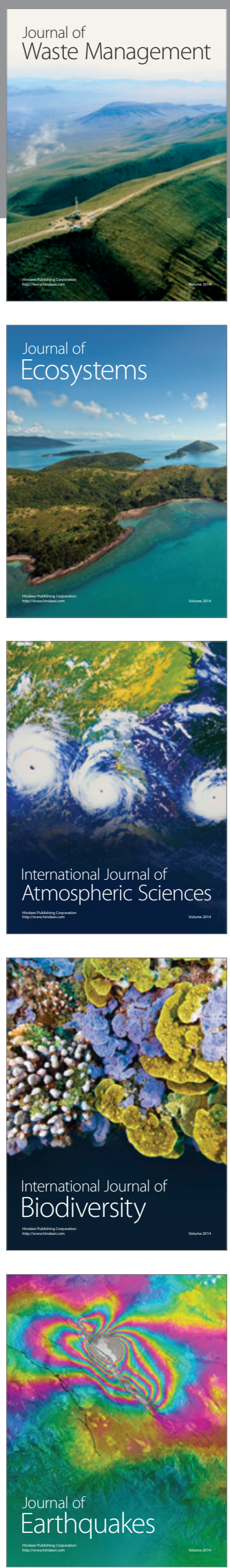
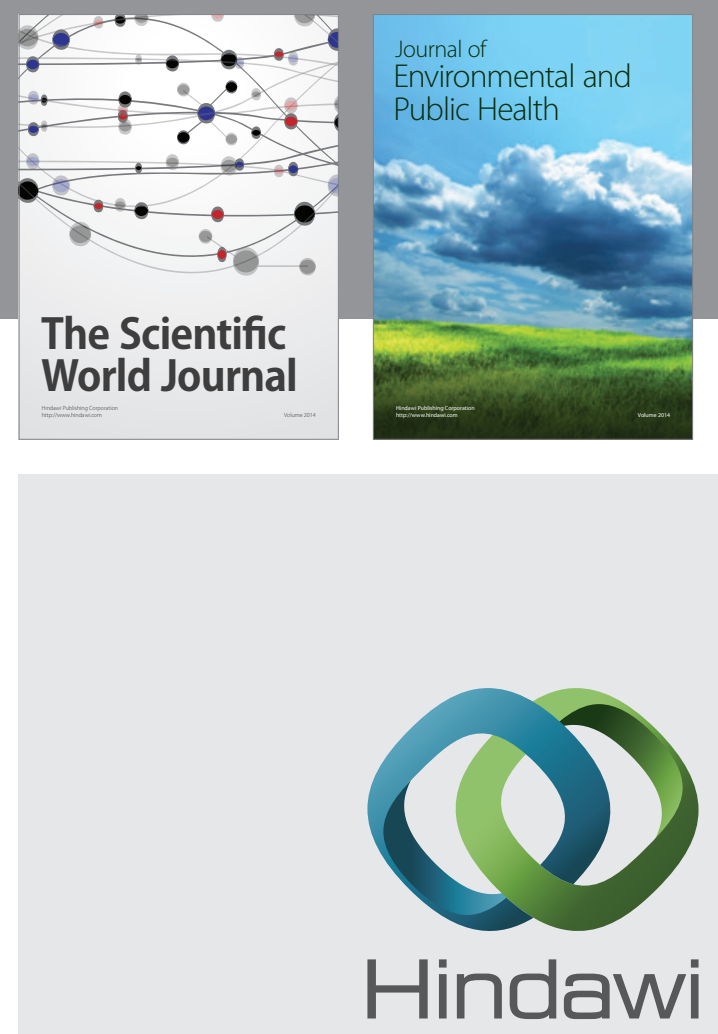

Submit your manuscripts at

http://www.hindawi.com
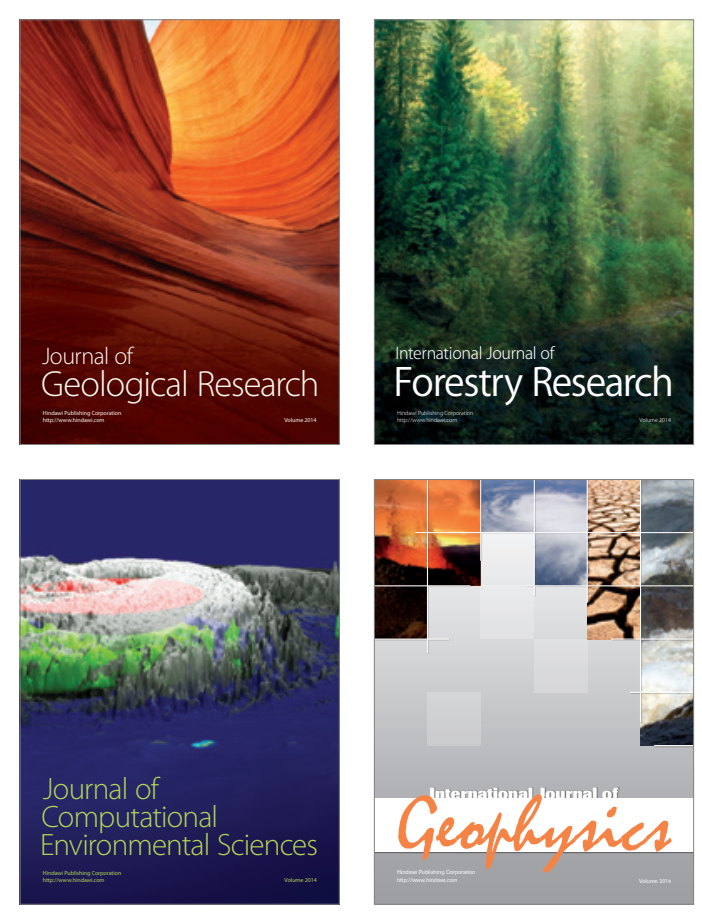
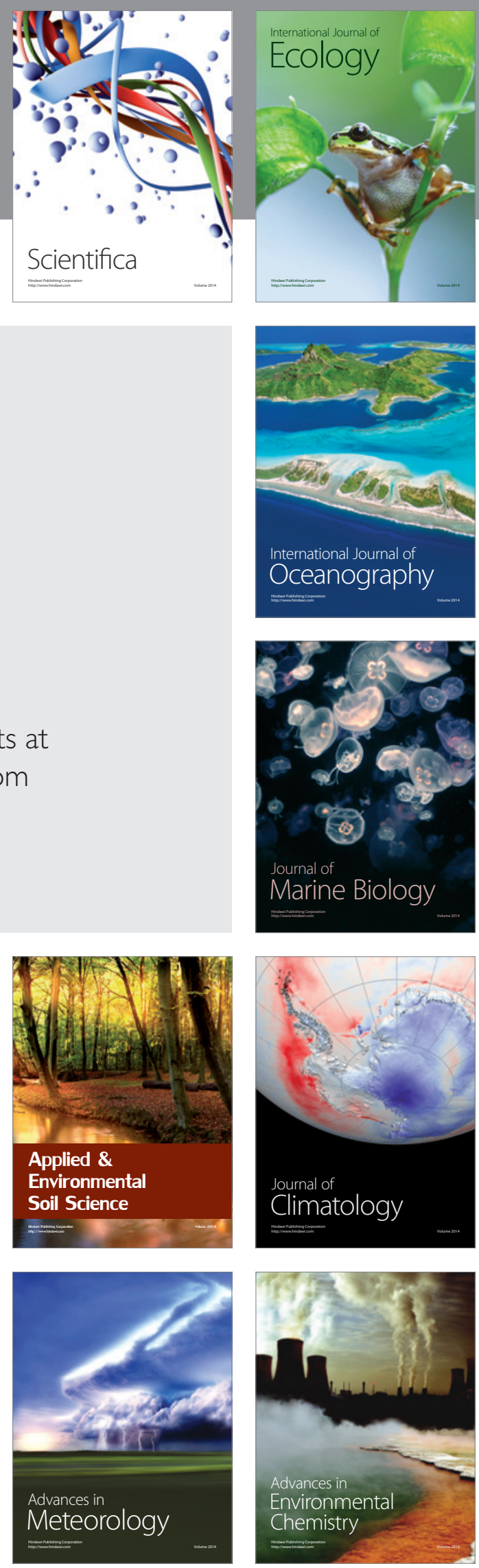